\title{
The Auditor-Valuation Specialist Coopetitive Alliance in the Fair Value Audit of Complex Financial Instruments
}

\author{
By: Dereck Barr-Pulliam, Jennifer Joe, Stephani Mason and Kerri-Ann Sanderson
}

\begin{abstract}
We conduct interviews with valuation specialists (specialists) employed by accounting firms (in North America, Europe, and the Asia-Pacific region) to understand how they work with auditors to evaluate the reasonableness of fair value measurements (FVMs) for financial instruments. The rapid growth of FVMs and complex estimates reported in the financial statements requires that auditors increasingly rely on specialists to perform these evaluations. Informed by coopetition theory from management and organizational science, we develop a framework to examine the tensions in the auditor-specialist alliance (the coopetitive alliance) and how those tensions can impact FVM audit quality. Our framework considers five factors that contribute to tensions in the coopetitive alliance - organizational structure, economic independence and stressors, project goals, group identity, and knowledge sharing. We find that tensions around the economic independence of the specialist unit, auditor delays in engaging the specialist, and specialists' perceptions that auditors do not respect their expertise and contribution to the FVM audit, lead specialists to distrust auditors and to respond in ways that threaten audit quality. Further, we show that firm-level choices in the organizational structure and policies governing the use of specialists can impact the perceived quality of the specialist unit and the quality of audited FVMs. Our research complements recent studies examining the role of specialists in audit engagements with significant complex estimates and provides new insights to academics, regulators, and professionals.
\end{abstract}




\section{Introduction}

We examine the perceptions of audit firm-employed valuation professionals (hereafter, specialists) who assist auditors in evaluating the reasonableness of fair value measurements (FVMs) for complex financial instruments (e.g., Level 3 securities valued by sophisticated models, not via pricing services) to understand how these professionals work together and how their collaboration impacts fair value financial reporting. ${ }^{1}$ The escalated growth in complex business transactions and the passage of financial reporting standards ASC 820 (FASB 2011) and IFRS 13 (IFRS 2011) resulted in "an increase[ed] use of estimates including fair value measurements" in audited financial statements (PCAOB 2017c). ${ }^{2}$ The preparation of some FVMs requires sophisticated valuation techniques that are highly susceptible to management bias (e.g., Hilton and O’Brien 2009). As a result, auditors increasingly rely on the work of specialists (e.g., PCAOB 2015a, 2017a, 2017b) because auditors typically lack the valuation expertise needed to evaluate the reasonableness of FVMs (Martin, Rich, and Wilks 2006; Joe, Janvrin, Barr-Pulliam, Mason, Pitman, Rezaee, Sanderson, and Wu 2015; Glover, Taylor, and Wu 2017). The increased need for specialist involvement in financial reporting and auditing, as well as the post-Financial Crisis regulatory scrutiny, of FVMs reported in the financial statements created an 'exogenous shock' that compelled two professional groups (auditors and specialists), who have different histories, to collaborate on the audit of FVMs (Barr-Pulliam, Mason, and Sanderson 2020).

Intra-firm collaboration between auditors and valuation specialists is unique in that (1) it did not evolve over an extended period like the auditor-IT specialist relationship, for example, (2)

\footnotetext{
1 The PCAOB identifies two types of specialists that auditors use to evaluate FVMs: (1) specialists employed by the auditor's firm (employed specialists), and (2) specialists employed by a third-party (engaged specialists). This study focuses on auditors' use of their employed specialists, which is the most common practice among large audit firms (e.g., PCAOB [2015a, 2017a]; Cannon and Bedard [2017]; Glover et al. 2017).

2 This manuscript uses the terms "fair value measurements” (FVMs) and “complex estimates” interchangeably.
} 
many of the professionals do not share a similar (accounting) educational background and the identical professional credential (e.g., in the U.S. auditors and tax specialists are CPAs), and (3) for most firms, the relationship did not grow organically by hiring talent over time. Instead, specialists report that audit firms primarily gained access to specialists' expertise through acquisitions of other valuation service providers (e.g., Donelson, Ege, Imdieke and Maksymov 2020). Our examination of the auditor-specialist relationship focuses on specialists who support auditors in the evaluation of complex financial instruments (CFIs), which, according to recent estimates, exceed $\$ 200$ trillion. ${ }^{3}$ Our examination of the auditor-specialist relationship is important because they work together to audit financial instruments that represent a significant portion of fair-valued assets reported on financial statements worldwide. While this study focuses on the auditor-specialist alliance for the valuation of CFIs, we identify factors that have implications for other auditor-specialist collaborations. A 2018 post-inspection analysis by the PCAOB indicates that among engagements completed by U.S. affiliates of global audit firms, approximately 85 percent of the audits used four to five specialists representing more than one specialized area (PCAOB 2018, 30). That estimate is consistent with Cannon and Bedard's (2017) observations that approximately 86 percent of engagement teams consult a valuation specialist (who overwhelmingly are audit firm-employed specialists).

We use coopetition theory in management and organizational science literature as a basis for developing a framework to understand the auditor-specialist relationship and how this intrafirm relationship can influence the quality of FVMs (e.g., Fernandez, Chiambaretto, Le Roy, and Czakon 2018). Specifically, we consider the coopetition literature focused on the part-competitive

\footnotetext{
${ }^{3}$ The Bank for International Settlements estimates the size of the global debt markets at about \$120 Trillion, Securities Industry and Financial Markets Association estimates the size of the global equity markets at approximately $\$ 75$ trillion, McKinsey estimates the size of the private equity and debt markets at approximately \$6 trillion, and MSCI Inc. estimates the size of the professionally managed global real estate investment market at approximately $\$ 9$ trillion.
} 
and part-cooperative alliance formed when cross-functional units within the same parent organization collaborate to achieve higher performance (outcomes) for the parent firm (Tsai 2002; Luo, Slotegraaf, and Pan 2006). Insights from coopetition theory are relevant to examining the auditor-specialist alliance because while auditors and specialists cooperate to evaluate the audit client's FVM, they typically work in distinct units (audit and consulting) that compete as separate profit centers in an accounting firm. Moreover, firm compensation systems incentivize audit and consulting partners to maximize their individual "book of business" and to prioritize their own unit’s profitability. ${ }^{4}$ For example, Donelson et al. (2020) note that audit and consulting units clash over which group has the right to control the audit firm. Similarly, many believe that the primary reason for Arthur Andersen's downfall was the audit practice's competitive drive to generate revenues so that it would not be overshadowed by the consulting practice (Chicago Tribune 2002).

We build on the coopetition literature (e.g., Tsai 2002; Luo et al. 2006; Fernandez, Le Roy, and Gnyawali 2014; Gnyawali, Madhavan, He, and Bengtsson 2016) to develop an intra-firm coopetition framework that incorporates the unique features of the audit environment and the auditor-specialist relationship. Our framework considers five key factors (economic independence and stressors, organizational structure, project goals, group identity, and knowledge sharing) that can exacerbate or reduce tensions in the auditor-specialist alliance. We also consider the potential influence of these factors on audit effort and audit quality of FVMs reported in financial statements.

\footnotetext{
${ }^{4}$ The book of business refers to a partner's profit and loss statement which lists their clients and the revenue and expenses attributed to that client. The book of business is the measure of the partner's contribution to their firm's earnings and determines the partner's compensation (i.e., partnership draw) at the end of the fiscal year. Interviews with partners in leadership roles at multinational and national accounting firms reveal that audit and consulting units tend to compete in a zero-sum game whereby any increase in fees allocated to one group from a shared fixed fee contract results in decreased fees to the other group. Similarly for overhead and joint firm costs, an increase in allocation to one unit directly reduces the costs allocated to other units in the same firm. Thus, even though units in a firm share a common brand name they are in conflict over cost and revenue apportioning.
} 
We use coopetition theory, which is focused on interactions between two or more units, to examine the dyadic auditor-specialist alliance and to acknowledge the role auditors play in understanding their interactions. Several studies have examined the auditor's role and perspective related to the audit of FVMs. This research provides a rich description of the interactions between auditors and specialists from the auditors' vantage point. For example, Boritz, Kochetova, Robinson, and Wong $(2020,4)$ note that “most prior research reports auditors' views about specialists" and Hux's (2017) review of the literature calls for future research on the use of specialists on audit engagements from the specialists' vantage point. These observations suggest that there is limited opportunity to gain additional substantive insights from the auditors' perspective on the auditor-specialist alliance. Considering the limited evidence on the perspective of specialists versus that of auditors, and acknowledging the ethics of using participants only when the benefits outweigh the cost of their time and involvement, we do not interview auditors.

We base our qualitative analysis on semi-structured interviews with 21 (high-level) specialists employed by international and national audit firms and who are domiciled in the AsiaPacific region, Europe, and the U.S. The interview approach allows us to explore tensions in the auditor-specialist alliance from the perspective of professionals directly tasked with assisting auditors in the evaluation of FVMs. This qualitative research approach is appropriate because our study aims to gain a richer, more comprehensive understanding of the auditor-specialist alliance as well as the judgment and decision-making process applied in practice to evaluate FVMs. The approach also allows us to gain constructive insights into previously unobservable factors influencing specialists' judgments that also influence the audit of FVMs. We provided participants a set of pre-interview questions along with a sample CFI designed to orient participants toward a similar level of CFI complexity when describing their interactions with auditors. 
Overall, we find that tensions between auditors and specialists can limit the efficacy of the coopetitive alliance. From the specialists' perspective, economic independence and financial concerns are the key issues that exacerbate tensions. First, specialists' fees and capitation rates are higher for external consulting than for audit support (Barr-Pulliam, Joe, Mason, and Sanderson 2019). Thus, specialists report tensions when auditors delay engaging the specialist until the lastminute, creating deadline pressures that interfere with the specialist's availability to work on more lucrative consulting projects (e.g., preparing FVMs for non-audit clients). Specialists report detesting tight deadlines because it forces them to operate in "crisis mode." The opportunity for higher earnings can prompt specialists to prioritize external consulting over audit support services, which can threaten effort and quality on the audits of FVMs.

Second, specialists perceive that auditors are reluctant to share audit fees with them to compensate for the valuation support service and that auditors exclude them from planning and scoping in order to limit fee sharing. Limits on the specialist's time and contribution to the evaluation of FVMs, whether due to deadline pressure or exclusion from planning, can reduce specialists' effort and lead to inadequate audits of the client's FVMs.

We also find that where the specialist unit is positioned within the firm's organizational structure and differences in professional background (i.e., related to client responsibilities and socialization) impact how the specialists approach the task of evaluating FVMs. Specialists report that the conditions which diminish tensions and contribute to a higher quality audit of FVMs include a firm policy to mandate consulting with specialists based on established engagement-specific thresholds, the existence of a national or international centralized specialist unit, and establishing a hybrid specialist role (experts experienced in both audit and valuation). A key difference in professional point of view that appears to frustrate specialists is their perception that auditors focus 
on materiality as a starting point to evaluate whether to retain a specialist to support the audit. Specialists view the focus on materiality as inappropriate. They assert that the starting point should be an examination of the financial instruments in the client's portfolio to ascertain the range of uncertainty and risk before consideration of either the client's point estimate or the materiality of that estimate. Specialists perceive that auditors prefer the primary output of the valuation task to be a point estimate and are driven by a "check-the-box" mentality. Specialists prefer to deliver a valuation range and a more comprehensive valuation product. They also believe that auditors do not understand the complexities and nuance in valuation, but appear willing to educate auditors on the valuation process both for self-serving reasons (i.e., to help auditors recognize the complexity of FVMs and the need for specialist support) and to improve the quality of the audits of fair value.

When specialists perceive a lack of respect or value for their expertise and contribution to the audit of FVMs, they distrust auditors. They are less willing to perform procedures that they perceive can reduce audit risk. Factors that contribute most to specialists feeling disrespected are auditors' delays in engaging them until the end of the audit, and auditors' attempts to evaluate FVMs without the specialist's support. Specialists believe such actions often result in impractical deadline pressures and are the byproduct of auditors' overconfidence in their ability to evaluate FVMs and their under-appreciation for the complexity of FVMs. Specialists also complain that auditors' willingness to overrule their recommendations in order to please their client is a source of tension that detracts from the auditor-specialist coopetitive alliance.

This study is the first to present an analysis of factors that, from the specialist's perspective, can influence how auditors and specialists work together and how their alliance can impact the quality of the FVMs reported in audited financial statements. Given that specialists are central to the auditor-specialist alliance on audit engagements, and their perspective is largely limited in the 
literature, this research contributes to understanding the use of specialists on audits. Our focus on the specialist's perspective complements prior studies exploring the auditor's perspective in their use of specialists (e.g., Cannon and Bedard 2017; Glover, Taylor, and Wu 2019; Boritz et al. 2020; Griffith 2020), and taken in conjunction with these prior studies affords a more holistic view of the auditor-specialist alliance in the evaluation of complex estimates. Our research has the potential to stimulate empirical studies that systematically examine the factors we identify that can enhance or detract from the auditor-specialist coopetitive alliance. Prior research suggests that auditors rely heavily on the work of specialists and that specialists influence auditors' risk assessments, planned testing, and evidence gathering (e.g., Griffith, Hammersley, Kadous, and Young 2015; Griffith, Hammersley, and Kadous 2015; Joe, Vandervelde, and Wu 2017; BrownLiburd, Mason, Shelton 2019; Griffith 2020). Given the high reliance placed on the work of specialists and the extreme measurement uncertainty associated with FVMs (Christensen, Glover, and Wood 2012), it is important to understand factors that can affect specialists' decision making when supporting auditors and how the coopetitive alliance influences reported FVMs.

We identify existing and offer new factors that impact intra-firm coopetitive alliances. Our analysis of these factors can be useful to audit firms interested in implementing interventions to improve the output and working relationship between auditors and specialists. This analysis is also relevant to other organizations that utilize intra-firm coopetitive alliances. For regulators, we provide insights on issues that can diminish or escalate tensions in the auditor-specialist alliance and how these tensions can impact the quality of reported FVMs. Regulators should consider these matters because lower quality FVMs could ultimately decrease the decision usefulness and value relevance of audited financial statements. 


\section{Coopetition Theory and Audit Practice Competition in cross-functional units}

In most of the large multi-national and national accounting firms, the audit and consulting units operate separately in silos to track revenues, costs, and net income. The firms do not pool profits across units when allocating partner compensation and, as noted earlier, specialists are employed in the consulting unit. Thus, the audit and specialist partners' annual draw and the bonus allocation for lower level professionals depend on the success of their individual unit. Conversations with partners in leadership roles indicate that firms believe this compensation structure shields them from regulatory scrutiny and criticism that including consulting fees from audit clients in the audit partner's compensation would threaten audit quality. Nonetheless, separate profitability silos promote competitive tensions across the units leading partners and unit leaders to treat revenues and resource allocations as a zero-sum game. Audit partners indicate that specialists refuse to accept lower realization rates or writedowns for specialist work on audits because it negatively impacts the specialist partner's book of business and the specialist's earnings on audits are closely monitored by the specialist unit managing partner. The audit and specialist units also compete for talent both at recruiting and transfers within the audit firm. Although they want to attract the best talent in the firm, audit partners resent that the consulting unit can offer higher compensation for their professionals. Audit and consulting units also compete over the leadership team composition and ultimately firm control. Partners report that to win election to the leadership board, candidates must be convincing that loyalty to their home unit will not bias their judgment. They reveal that in the run-up to firm leadership elections, there is significant "jockeying and back-room dealing" as the units fight to ensure that the individuals named to the leadership team will represent and consider their unit’s interest. 


\section{Coopetition in cross-functional units}

We use insights from coopetition theory and the related organizational management literature to develop a framework that describes the alliance formed between specialists and auditors - professionals from different units in audit firms - in order to evaluate the reasonableness of audit clients' FVMs. The framework allows for an understanding of how this intra-firm coopetitive alliance can influence the valuation product ultimately delivered to the audit team. Historically, the strategy and organizational management literature focused on either competitive advantage theory (Porter 1980) or collaborative advantage theory (e.g., Gulati, Nohria, and Zaheer 2000). These theories held that companies engaged in 1) a competition paradigm, where parties have opposing interests that create a win-lose or zero-sum game scenario (Walley 2007) or 2) a cooperation paradigm, which emphasizes the benefits of collaborating by exploiting inter-firm interdependencies with fully converging interests (Gulati, Wohlgezogen, and Zhelyazkov 2012). These opposing, and one-sided, views were eventually reconciled. Coopetition theory reflects an understanding that competition and cooperation are both necessary, but alone, insufficient to develop strategic interdependencies in organizations that operate in common markets. Coopetition, partial competition and partial cooperation, results in a win-win strategy for firms (Bengtsson and Kock 2000; Shih, Tsai, Wu, and Lu 2006).

Ray Noorda (CEO of the now-defunct Novell Netware technology firm) is credited with coining the term “coopetition" to describe Novell's relationships with other information technology firms (Brandenburger and Nalebuff 1996). Academics adopted the term to holistically evaluate the economic and social factors that underlay collaborations across firms and or industries (inter-firm coopetition) (e.g., Kang, Lennox, and Pandey 2019; Bills, Hayne, and Stein 2020) and more recently across units in the same firm (intra-firm coopetition) (e.g., Feichter, Grabner, and 
Moers 2018; Fernandez et al. 2018). Intra-firm coopetition describes alliances between crossfunctional units that are engaged in a joint project(s) designed to achieve higher performance (outcomes) for the firm (Brandenburger and Nalebuff 1996; Lado, Boyd, and Hanlon 1997).

Coopetition describes the dual and paradoxical relationship and strategic dynamic process (Bouncken, Gast, Kraus, and Bogers 2015) where economic actors simultaneously cooperate to create value and compete to capture a higher share of the value generated from the jointly created product (Peng, Pike, Yang, and Roos 2012; Ritala 2012). For example, coopetition allows the participating units to combine complementary knowledge and to develop successful product innovation (Quintana-García and Benavides-Velasco 2004; Gnyawali and Park 2009, 2011; Ritala and Hurmelinna-Laukkanen 2009). Often there is high uncertainty associated with the success of the coopetitive alliance. Cross-functional units also have sufficient incentives to behave opportunistically, which inhibits the formation of trust between units (Arranz and Arroyabe 2008; Czakon and Czernek 2016). Cooperation helps each unit to improve existing knowledge or to gain new knowledge, and to exploit economies of scope. Competition between units occurs because organizations typically evaluate each unit separately based on that unit's ability to achieve predetermined contributions to the organization's operational efficiency and profitability (Tsai 2002; Donelson et al. 2020). However, a win-win coopetitive alliance can help a firm to disseminate knowledge across units, and this knowledge can serve as a "strategic asset" in the marketplace (Luo et al. 2006; Menon and Varadarajan 1992). Le Roy, Fernandez, and Chiambaretto (2018) hold that how well the coopetitive alliance is managed is a predictor of whether a coopetitive strategy leads to higher performance relative to other strategies like a winwin or a win-lose strategy. 
Much like a traditional teeter-totter, healthy coopetition can act as the fulcrum balancing varying degrees of cross-functional competition and cooperation. Further, continuing with the teeter-totter analogy, some factors can shift the balance in the coopetitive alliance more towards a competitive or a cooperative state. Imbalance in the coopetitive state that does not meet the satisfaction of the cross-functional units gives rise to tensions in the alliance. It can affect the quality of the coopetitive project (Tjosvold, Johnson, Johnson, and Sun 2003). This view is consistent with the debate in organizational research on whether agreement or disagreement in teams is "advantageous for overall performance” (Weingart and Jehn 2000, 327).

\section{[Insert Figure 1]}

\section{Fair Value as a Coopetitive Project for Auditors and Specialists}

The collaboration between auditors and specialists to evaluate the reasonableness of FVMs can be viewed as a coopetitive alliance. That is, although they work together, the cross-functional team comprised of auditors and specialists represents separate units within the firm. Generally, the auditor and specialist units are separately accountable to and evaluated on performance by the firm. Audit firms commonly separate these units functionally, whereby specialists are a part of the firm’s advisory practice (Joe et al. 2015). However, even when both practice areas reside within the audit function, firms can evaluate their performance separately. In some situations, auditors and specialists compete for the client because clients who are impressed with the specialists have terminated the auditor in order to retain the specialist for financial statement preparation and other consulting services. ${ }^{5}$ Thus, at times auditors compete with specialists to be viewed as the experts in the eyes of the client (Griffith 2020). Also, firm leadership can make strategic decisions based on firm profitability or risk management to shed the audit service in favor of providing consulting

\footnotetext{
${ }^{5}$ Specialists in CFIs provide audit support, financial statement preparation support for non-audit clients and other consulting services such as deal issuances. For economy, we use "non-audit" to reflect all services other than audits.
} 
services for the client. Doing so puts audit and specialist partners in competition over whose portfolio gets the client (Donelson et al. 2020).

In addition, even when cross-functional units have a favorable view of the coopetitive alliance, tensions can still arise as the units collaborate to create shared value for the firm and while attempting to appropriate private value from the alliance (e.g., Ritala and Tidström 2014). In auditing, the firm-level task of evaluating clients' FVM is owed by auditors because they bear primary responsibility for the audit (Hux 2017). Accordingly, auditors determine how much of the total budgeted hours will be allocated to the audit of a client's FVMs. Within the budget specific to FVMs, auditors apportion the amount of work that will be performed by the audit unit versus the specialist unit. Because auditors have control over the revenue associated with the coopetitive task, yet specialists are required by firm leadership to contribute to the task, there is conflict over the allocation of effort and the associated audit fees. Vying for a 'fair share' in the apportionment of the FVM budget contributes to the competition within the auditor-specialist alliance.

The coopetition literature is in its infancy (Bouncken et al. 2015). It distinguishes two factors that could affect tensions in a coopetitive alliance by either fostering or limiting the strength of, and satisfaction with, the alliance: organizational structure (Chakravarthy, Zaheer, and Zaheer 1999; Hansen 1999; Bhatt 2001) and knowledge sharing (Tsai 2002). We review the strategic management and organizational science literature and suggest three additional factors that contribute to tensions in coopetitive relationships: economic dependencies and stressors, project goals, and group identity. For simplicity, we discuss the application of each of these factors separately, and as they relate to the auditor-specialist coopetitive alliance. We acknowledge, however, that these factors could be interrelated, dual directional, or mutually reinforcing in practice (e.g., Tsai 2002; Luo et al., 2006). 
Organizational structure refers to the policies and formal structures put in place by the institution to govern coopetitive units and their interactions, as well as other units in the firm. Organizational structure has a significant impact on the coopetitive alliance because coordination governed by the parent via a vertically imposed bureaucratic process limits discretion and discourages the operation of informal networks across employees in the participating units (Tsai 2002). A firm-imposed organizational structure leads to decreased motivation to contribute to a coopetitive product and detracts from a healthy coopetitive alliance (Tsai 2002). In the audit of fair value setting, processes used to govern the auditor-specialist coopetitive alliance such as centralization of the specialist support service or mandatory specialist consultation, could affect auditor-specialist interactions and limit the potential for building trust among professionals (Tsai 2002). Such structures can increase tensions when auditors and specialists feel forced into the alliance (e.g., Johnson, Hollenbeck, Humphrey, Ilgen, Jundt, and Meyer 2006).

Economic dependencies and stressors refer to the conflicts related to 1) the allocation of resources between the parties in the coopetitive alliance (Tsai 2002; Luo et al. 2006) and 2) the extent to which each party is resource independent (e.g., Fernandez et al. 2014). Specialists face a unique predicament requiring them to tradeoff between the demands of their dual roles as evaluators of FVMs in support of the audit of fair value and as preparers of initial FVMs for nonaudit clients (Joe et al. 2015). Audit firms evaluate each unit in a coopetitive alliance based on their rate of return (and value provided to the parent organization) and use these assessments to allocate firm resources (Donelson et al. 2020). Consequently, a conflict could arise over the economic benefits each unit extracts from the alliance. Specialist units receive a share of the audit fee for their work, and auditor control over determining this allocation can exacerbate tensions in 
the alliance. The tension is particularly salient when auditors seek to control specialists' work, that is, limit their hours and usage (Bratten, Gaynor, McDaniel, Montague, and Sierra 2013).

Further, Donelson et al. (2020, 29) indicate that, from a “practical perspective,” dual role professionals such as those performing audit as well as non-audit services are compensated not based on "how well they assist the audit," but instead on how well they "deliver the consulting results." Therefore, demands on the specialist unit to be economically self-sufficient and competition among units for firm resources can exacerbate tensions in the auditor-specialist coopetitive alliance. That is, the time required to service audit clients creates an opportunity cost because it constrains the time available to provide valuation services to more profitable non-audit consulting services. The opportunity cost can directly affect specialists' economic viability.

Project goals refer to each unit's orientation towards the coopetitive product and whether the units' goals are aligned. When participating units hold a shared understanding and work towards common goals, it enhances the coopetitive relationship. Gnyawali and Park (2011) find that the successful implementation of shared goals in a coopetitive alliance reduces tensions and enhances the balance of the alliance's cooperative and competitive interactions. Divergent goals, however, limit coordination and detract from the coopetitive alliance (e.g., Fernandez et al., 2014). Donelson et al. (2020) interviews auditors and observe that auditors have audit quality-related goals on audit engagements and conjecture that professionals providing dual roles within the firm (e.g., specialists) are more driven by commercialistic goals and incentives on engagements. Together, the auditing and coopetition literature suggest divergence in goals across units could contribute to tensions in the auditor-specialist alliance.

Group identity refers to the extent that members of the coopetitive alliance share a collectivist view that embodies the unified goals and strategies of the parent organization. The 
alternative view is a focus on a salient social and psychological bond with the functional unit (Iyer, Bamber, and Barefield 1997; Willer 2009). Prior research finds that the more salient the collective identity, the less likely that intergroup tensions arise (Wasko and Faraj 2000; Bauer and Estep 2019). That is, the stronger the salience of the collective identity in the auditor-specialist alliance, the less likely that tensions dominate the coopetitive relationship.

Knowledge sharing refers to the willingness of units in an alliance to share knowledge related to the coopetitive product (Tsai 2002). That is, knowledge sharing plays a pivotal role in strengthening the alliance and enhancing the joint output (Tsai 2002; Luo et al., 2006). Each unit's knowledge represents its distinct competitive advantage and is the basis for the value each unit contributes to the joint product (e.g., FVM audit). Prior research finds that trust undergirds effective knowledge sharing (Davenport and Prusak 1998; Ichijo, von Krogh, and Nonaka 2000) and facilitates communication among team members (Dodgson 1993). Bills et al. (2020) finds that trust is a strong relational mechanism that can enhance collaboration and mitigate coopetitive tensions. Distrust can deter knowledge sharing and heighten tensions that erode the alliance (Loebecke et al. 1999; Luo et al. 2006). Prior audit research highlights that knowledge sharing is critical in the auditor-specialist alliance because auditors have difficulty interpreting and ineffectively use the specialist's work, and specialists have limited understanding of the audit processes and documentation requirements (Barr-Pulliam et al. 2019; Griffith 2020).

We note a key difference in our development of a coopetitive framework that facilitates examination of tensions arising during the audit of FVMs. Coopetition literature in the field of management views knowledge and knowledge sharing as a coopetitive resource or project output where there is a "collective use of shared knowledge to pursue common interests" (Tsai 2002, 180). In management contexts, competition between teams arises when appropriating shared 
knowledge, an outcome gained from the alliance used to outperform the other team (Khanna, Gulati, and Nohria 1998). This view, however, does not directly map to the auditing context. Auditors typically lack sufficient knowledge to evaluate the reasonableness of clients' FVMs effectively. Consequently, they rely upon audit firm-employed specialist's knowledge and expertise to complete the audit task (Martin et al. 2006; Bratten et al. 2013). Thus, in the auditorspecialist coopetitive alliance, the flow of knowledge is primarily from specialists to auditors, and the degree that specialists share knowledge is a factor that can contribute to tensions in the alliance.

Further, the outcome of the auditor-specialist alliance is the specialist's valuation report, which documents their evaluation. While auditors are likely to gain knowledge from working closely with specialists over time, findings from regulatory inspections and research suggest that the knowledge they acquire will be insufficient to allow auditors to perform evaluations of FVMs independently (PCAOB 2015b; Glover et al. 2019). Prior research finds that even the most organized efforts to share knowledge are often impeded by an individual's tendency to share information selectively (e.g., Gilmour 2003; Luo et al., 2006). Accordingly, our theoretical framework considers knowledge sharing as an antecedent to coopetition rather than an outcome that, in turn, can exacerbate or diminish tensions in the auditor-specialist coopetitive relationship.

We considered alternative theories to guide our analysis of the auditor-specialist relationship during the audit of FVMs. Specifically, we considered social exchange theory (Deutsch 1949) and institutional theory (e.g., Scott 2014). Social exchange theory posits that people interact based on the perceived costs (e.g., time or resources expended) and benefits (e.g., resources acquired or knowledge gained) gained in a relationship (e.g., Tjosvold et al. 2003; Johnson and Johnson 2005). A key premise in social exchange theory is that the parties make an informed choice as to whether they will enter the exchange. Because specialists and auditors in 
our setting work within the same audit firm, and the current regulatory structure often imposes that auditors engage specialists to complete the FVM audit, we determined that social exchange theory was not suited to this context.

Similarly, in the audit setting, institutional theory has been applied to describe how organizational structures, rules, norms, and routines shape social interactions and professional behaviors within organizations over time (Scott 2014). Professionals are thought to adopt routinized behaviors to achieve legitimacy in the eyes of those who govern or exercise power over the professionals (e.g., DiMaggio and Powell 1983). While this theory could help to explain how specialists adapt to and approach their role in the audit of FVMs, it is ill-suited to describe the dual and paradoxical nature of auditor-specialist interactions and how those interactions impact audited FVMs. Consequently, we use tenets from coopetition theory to develop our framework to evaluate tensions in the auditor-specialist alliance.

\section{Research Method}

\section{Approach and participants}

In this section, we explain the research approach and process to analyze participants' responses in a manner that is trustworthy and authentic (Golden-Biddle and Locke 2007; Jonsen, Fendt, and Point 2018).

Our participants are 21 valuation specialists (81.0\% male; 19.0\% female; Table 1 Panel C) with extensive experience assisting auditors in the evaluation of complex Level 2 and 3 fair values. ${ }^{6}$ During the interview, all participants were employees of audit firms registered with and, thus, inspected by the PCAOB (85.7\% from annually-inspected and $14.3 \%$ from triennially-

\footnotetext{
${ }^{6}$ Approval for this human-subjects study was granted by the Institutional Review Board (IRB). Our sample size was guided on meeting saturation point and is similar to that of contemporaneous accounting studies on related issues (e.g., Griffith et al. 2015a; Westermann, Bedard, and Earley 2015; Jenkins, Negangard, and Oler 2018; Griffith 2020).
} 
inspected firms; Table 1 Panel A). Our participants are highly-experienced professionals; 16 (71.4\%) had at least 11 years of valuation experience and all serve in senior-level positions such as Senior Manager, Managing Director, or Partner at their firms (Table 1 Panel A). Seven (33.3\%) have prior auditing experience (Table 1 Panel B), and nineteen (90.5\%) hold at least one credential: 13 (61.9\%) are Certified Financial Analysts (CFAs), and six (28.6\%) are CPAs (Table 1 Panel C). These participants operate in offices located across North America, Asia-Pacific, and Europe and, thus, can provide a global perspective on the auditor-specialist alliance (Table 1 Panel A). Participants have the most prior experience at other Big 4 (38.1\%) and Non-Big 4 (47.6\%) accounting firms and financial institutions (33.3\%) as shown in Table 1 Panel B. Participants report evaluating an average of 79.0 Level 3 financial instruments annually for auditors and preparing 120.7 annually for non-audit clients (Table 1 Panel C). Overall, our participants are representative of the general population of valuation specialists that assist in the audit of fair value and are qualified to describe the nature of their work with auditors in that setting. Table 1 also describes the participants' educational background and overall experience.

[Insert Table 1 here]

\section{Procedures}

We leverage qualitative studies in the accounting and auditing domains (e.g., Covaleski, Dirsmith, Heian, and Samuel 1998; Trompeter and Wright 2010; Westermann, Bedard, and Earley 2015; Downey and Westermann 2019; Griffith 2020; Bills et al. 2020), as well as guidance on field study methods (e.g., Power and Gendron 2015; Malsch and Salterio 2016) to inform our research approach. We employ a semi-structured interview approach because it allows us to delve deeper into specific themes to gain an understanding of how specialists' interactions with auditors can influence the audited fair value estimates (Miles and Huberman 1994; Lillis 1999). It also 
allows us to gain insights beyond those obtainable from surveys or experiments (Hirst and Koonce 1996; Gendron, Bédard, and Gosselin 2004; Beasley, Carcello, Hermanson, and Neal 2009).

We developed a semi-structured interview script with probing questions by integrating themes from prior research and insights obtained from early interviews with non-participant valuation practice leaders. A senior valuation specialist and a valuation practice leader, each employed at a Big 4 firm, reviewed, and edited the interview questions. We designed questions that would encourage participants to elaborate on the subject matter without influence or interruption from the research team (Huber and Power 1985; Lillis 1999). The final version of our interview protocol contained 8 semi-structured questions (some with follow-up questions) that were open-ended and neutral in nature (Hirst and Koonce 1996; Power and Gendron 2015. Before delving into interview questions, we established rapport with each specialist by describing the purpose of our study, obtaining informed consent, and assuring response anonymity. ${ }^{7}$ We also took this approach to encourage interviewees to provide candid responses (e.g., as suggested by Huber and Power 1985; Miles and Huberman 1994). We conducted interviews until we reached the saturation point where we began to hear qualitatively similar responses to our questions (e.g., Morse 1995, 2000; Sandelowski 2008).

To illustrate the level of complexity of FVMs that this study investigates, participants received a sample CFI based on a real Level 3 CDO secured by commercial and residential mortgages with different credit ratings, subordination, and margin percentages. The senior valuation specialists who reviewed our interview script also reviewed and validated the complexity of the sample case. Participants used the case facts as a reference to calibrate and stimulate

\footnotetext{
${ }^{7}$ We informed participants in the pre-interview materials that the purpose of the interview was to understand the role of valuation specialists in financial reporting and their interactions audit teams when evaluating the fair value estimates of complex financial instruments (such as structured securities/assets) in financial statements.
} 
responses about typical interactions with audit teams when evaluating material complex FVMs for publicly traded audit clients.

At least three researchers conducted all interviews with one researcher serving as the lead interviewer. To establish a consistent tone and approach across all interviews, researchers other than the lead interviewer acted as detailed note-takers, highlighting key insights. We conducted the interviews via telephone, and they lasted an average of 64 minutes. We developed a single transcript for each interview and made them available for participant review; however, no participants requested changes.

\section{Analysis}

In order to use theory to explain the themes we observed in our responses, we approached our analysis of the interviews with a "broad knowledge of potential theories that can provide potential explanations of the patterns observed” (Malsch and Salterio 2016, 5). We first read a sample of interview transcripts to gain an understanding of general themes in the responses (Layder 1998). We identified responses that resonated as "key, essential, striking, odd, interesting things people say or do as well as for repetition” (Rapley 2011, 277). In this way, we broke each interview transcript into chunks that represented “themes.” In addition to identifying patterns and commonality among themes (Patton 2015), we also looked for contradictory responses (e.g., Silverman 2010) across interviews, which allowed us to examine opposing viewpoints as well. Identifying contradictory responses lead the research team to iteratively discuss different theoretical lenses that allowed us to examine our research questions effectively and best explain our pattern of results. Coopetition theory best explained the patterns that emerged from our data (Malsch and Salterio 2016). 
We developed our five-factor coopetitive framework based both on the themes that emerged in the interview transcripts and research on intra-firm coopetition (e.g., Tsai 2002; Luo et al. 2006; Fernandez et al. 2014). From the transcripts, we used the perceived importance and frequency of participants’ comments to identify the associated coding category that best explained the tensions specialists perceive when interacting with auditors in the coopetitive alliance. Specifically, in addition to organizational structure and knowledge sharing considered in the prior literature, our framework identifies economic dependencies and stressors, project goals, and group identity as factors in the coopetitive alliance. Thus, we offer a unifying framework that contributes to theory by delineating the five factors and how they influence coopetitive tensions.

Using the coopetitive theoretical lens, each researcher individually coded six interviews (randomly chosen), compared coding, and met to reconcile any differences. Subsequently, two researchers individually coded the remaining 15 interviews. We used Nvivo to facilitate the extraction, coding, and analysis of our interview transcripts. ${ }^{8}$ All members of the research team identified, discussed, and resolved any identified differences to develop a consolidated dataset. The research team then reviewed quotes in each thematic coding category to collectively identify “power quotes" that succinctly illuminate participants' insights as well as "proof quotes” that represent general sentiments expressed by most participants (Westermann et al. 2019; Pratt 2009). Our objective was to ensure a good fit between the data and the guiding theory (Yin 2014).

To ensure the integrity and trustworthiness of our analyses (e.g., Lincoln and Guba 1985), we employ deviant analysis and respondent validation. We examined variations in participant responses and, where applicable, report sentiments that differ from the general themes we observe (e.g., Rapley 2011). Our respondent validation included sharing drafts of the manuscript and

\footnotetext{
${ }^{8}$ Inter-rater agreement among coders was 92.9\% percent, with a Cohen’s K of 0.80, which indicates a “good” level of initial agreement (Cohen 1960; Cicchetti 1994).
} 
presenting the findings to the PAC and IAASB Board. The Board included several representatives of audit firms that provided access to interview participants. Two Board members were accounting academics with experience conducting valuation-related research, and two other Board Members have expertise in coordinating valuation services within Big 4 firms. All PAC members had fair value audit expertise from either a regulatory or a practitioner perspective. Their iterative review of preliminary findings submitted during the grant review process helped validate the reasonableness of our interpretation of the interview data.

\section{Results}

\section{Organizational Structure}

Coopetition research finds that organizational structure plays a significant role in facilitating or inhibiting relationships and shaping the working dynamics of coopetitive teams (Chakravarthy et al. 1999; Hansen 1999; Bhatt 2001). In addition to impacting coordination between the coopetitive units, organizational structure can determine the extent to which the parent firm reaps enhanced capabilities and maximizes returns from coopetition (Kogut and Zander 1996;

Grant 1996; Gulati and Singh 1998; Tsai 2002). Management's coordination and the imposition of a hierarchical structure to govern units in the coopetitive alliance generally are ordered around three broad mechanisms (centralization, specialization, and formalization) that can influence tension between the parties (Luo 2005). Centralization refers to the level at which decision-making is concentrated within the firm (Aiken and Hage 1968; Tsai 2002; Jansen, Van Den Bosch, and Volberda 2005). Specialization refers to the range and number of tasks assigned to the unit where fewer tasks signal higher specialization (Mintzberg 1979). Formalization refers to the extent of standardized policies, rules, and procedures in place to govern the inter-unit alliance (Martinez and 
Jarillo 1989; Ayers, Dahlstrom, and Skinner 1997), clarify functional responsibilities (Menon, Bharadwaj, Adidam, and Edison 1999), and prescribe task approach (Jansen et al., 2005).

In the auditor-specialist coopetitive alliance, most specialists performing valuations for CFIs tend to specialize in this narrow area because, unlike business valuation services, the products are multi-structured, and there is pressure to remain current with the new tools required to value these assets (Barr-Pulliam et al., 2019). Accordingly, our analysis focuses on the formalization and centralization components of organizational structure.

In the fair value audit setting, centralization describes how the specialist unit is organized within the audit firm. Some firms establish a central firm-level or national-level specialist unit (i.e., valuation group) that services all audit engagements and non-audit clients. Other firms use a decentralized structure where each major office or region has its specialist unit located and dedicated primarily to serve that specific local or regional office.

The group has four teams, and one is doing what we call "hand-pricing" ...[e.g.,] valuing swaps, ... but we actually hand-price and independently value different types of products. [My] group services all the audit teams with one consistent pricing point. They [use a] form to submit the instrument, and we help them do things they can't do and that they can't go to a pricing vendor and get pricing for. All clients will have the same price for the same instrument. P9 Big 4 U.S.

This description indicates that one advantage of centralization is that it allows the specialist unit to provide a consistent level of service and valuation across clients. Specialists generally described centralization as their preferred structure because it provides opportunities to hone their skills for specific products and to assign professionals with task-specific expertise on audit engagements.

Our [Firm and valuation group name redacted] ...is our center of excellence for providing valuation audit support as it relates to traded derivatives and securities...We have a structured products team, and then we've got a team that specializes in corporate and municipal bonds, and then we've got another set of folks that are experienced in loans, etc. P8 Big 4 U.S. 
Within the centralized structure, some firms use hybrid-specialists in the audit practice that serve as liaisons between the audit and specialist units. This specialized group comprises professionals who have significant audit and valuation expertise. The hybrid-specialist represents a knowledge integration mechanism, which prior research suggests can be key in translating communications in cross-functional collaboration (Griffin and Hauser 1996; Olson, Walker, and Ruekert 1995) and enabling organizations to increase the likelihood of realizing high-quality solutions - valuations in our setting (Tsai and Hsu 2014).

Each audit team also has what's called a "financial instruments valuation [hybrid-specialist]" assigned to them. Those [hybrid-specialists]...know enough about valuation tools, techniques, and behaviors, but they aren't part of our valuation specialists group. They are trained in helping our audit team assess their clients' portfolios and provide them guidance and thoughts on how the audit team should look at that portfolio, what sort of sampling they should do. The [hybrid-specialists] will then get us involved. P8 Big 4 U.S.

In contrast to the centralized organizational approach, specialists believed that a decentralized approach detracts from the quality of the valuation service produced by the specialist unit and impairs specialists' competence:

The difference, I believe, is in organization. They have not organized around a dedicated group. They have people who do this, but I don't think that they've really created a dedicated group... they have not centralized its leadership...My understanding is that [Firm name redacted] is organized on office profit centers, and it's hard to build a really good group because no office has enough business to provide the experience necessary to be really good. And no office has the incentive to transfer the work to someone else. So, you're gonna have islands within [Firm name redacted], and they will tend to be not as good... [It also] ends up with people in other offices than New York doing stuff that they're not capable of doing. P3 Big 4 U.S.

[We also have] a strong, central audit technical team. They're providing technical guidance and undertaking a hot review before the audit being signed, independent of the partner review process. P5 Other Annually-Inspected INTL

The prior literature finds that greater centralization can create tensions (e.g., Menon, Jaworski, and Kohli 1997; Pertusa-Ortega, Zaragoza-Sáez, and Claver-Cortés 2010; Tsai 2002) in the coopetitive alliance. More decentralization promotes informal associations that enhance 
coopetitive relationships. Interestingly, our discussions reveal that the F.V. audit setting does not conform to that norm. Instead, except for observations and concerns around the quality of FVMs produced, specialists did not convey that centralization affected their relationship with auditors. It is possible that CFIs specialists, unlike workers in prior studies, enjoy the intellectual challenge and autonomous nature of their work, and hence do not need the benefit of informal associations.

Formalization, the third mechanism governing organizational structure, in the auditorspecialist alliance, applies to the process controlling the use of specialists. Broadly, firms employ either a mandatory or discretionary policy governing when and how auditors are required to use/consult with the specialist unit to support the audit of the FVMs. Some firms have a detailed prescriptive approach to control when and how specialists should be engaged, but the procedures around these mandatory consultations can differ across firms, as described below.

We have an internal team which would tell all the audit teams, "As soon as you see the following instruments, you have to contact the specialist team." If they have share awards that have been issued, or any swaps that they have, or forward contracts, or whatever type of instrument, they will have to contact us before they proceed with the audit... There's some internal guidance on when they need to contact us. P6 Other Annually-Inspected INTL

If an audit team would like to consult with a specialist, and per firm policy, there are certain situations in which they're mandated to. They will fill in a short form in that system, [with details] at a high level [and] the accounting standards that are applicable. We have a central coordinator who will then allocate those requests out to different specialists across the firm. We always have a specialist and a reviewer assigned to every consultation. You'll have a specialist who will do the work...a reviewer who will review the work, and get involved if there are issues, or differences that need judgment. (emphasis added) P11 Big 4 INTL

Other firms allow complete discretion over the decision to utilize a specialist, and this can lead to a lack of shared understanding of each unit's role, as indicated by the following:

The way it's structured is fairly independent ... There's no active supervision I would say, in the sense that they have a plan and there's a process setup, and they'll have team members contact me for my part, and I do my part. My summary product is reviewed by whomever is allocated that task and then the partner does their review and the professional practice group reviews that and so on and so forth. I'm not exactly familiar because I'm not an auditor, but 
that's the basics. There's nobody ... Once in a while, people will phone me and ask me specifics, but usually, it's completely hands-off. P10 Triennially-Inspected U.S.

The literature finds that mandatory consultation helps to align objectives across units and enhance inter-unit cooperation (Garrett, Buisson, and Yap 2006). Our discussions revealed that a discretionary process that allows audit partners to choose when to consult with the specialist could contribute to tensions in the coopetitive alliance in two ways. First, specialists reported that auditors often attempted to complete valuations "above their pay-grade," and when the quality control reviewer forces them to obtain a specialist, the auditors are resentful. For example, one specialist described an encounter of this nature with an audit partner, which shows that the quality of FVMs is at risk when audit partners have discretion over when to involve the specialist:

He was Googling, and he found some binomial lattice model downloadable in Excel... He couldn't understand why we were saying his fair value was out by, I think it was out by two million dollars. We had to literally go and fix the model for him, to show him what he needed to do to show, "This is how your model should be working...This is how it compares to our model." Then he just said, "Okay, fine, change it. I don't agree, but change it." P6 Other Annually-Inspected INTL

Second, when partners have discretion over the use of specialists, the audit engagement team might attempt the valuations on their own and only engage the specialist when that approach fails. Also, the partner might resist using the specialist until s(he) is forced to do so. At that point, they end up seeking the specialist's assistance in the final stage of the audit, thereby imposing tight deadlines on the specialist. These time pressures, which the specialists referred to as "fire-drills," are a frequent source of tension between auditors and specialists. Specialists indicated a preference for mandatory consultation within their audit firm because it limits the incidence of fire-drills.

In general, there are a lot of...fire-drill emergencies, where it's last minute...If I look back two or three years, it got a lot better as over time those kind of structures [i.e., mandatory consult] were put in place, albeit far from perfect and probably maybe went from $70 \%$ of audit interactions being an emergency to 20\%. P5 Other Annually-Inspected INTL 
A summary of the key findings discussed above related to Organizational Structure and the ensuing factors discussed below are presented in Table 2.

[Insert Table 2 here]

\section{Economic Dependencies and Stressors}

As audit firm employees, specialists must balance their roles as evaluators, supporting the audit, and consultants for non-audit clients. Balancing work across these two roles can create stress for specialists and exacerbate tensions in the coopetitive alliance because specialists have incentives to generate sufficient revenue to maintain a viable valuation practice. Maintaining a viable valuation practice affords more economic independence so that the specialist units are not wholly dependent on revenue earned from servicing audits. However, being housed within an audit firm does provide substantive economic security for specialists. For example, it provides a builtin client base and opportunities for referrals from other audit firms. Still, specialists place a high value on the consulting role because it is more lucrative - the billable rate and revenues per project are higher on consulting services for non-audit clients. Therefore, any time spent in the evaluator role represents an opportunity cost in terms of time available for non-audit services.

You have to keep people engaged in both directions, but it's interesting...because we make a lot of money, quite frankly, on large scale operational accounting projects. P9 Big 4 U.S.

The level of economic support that audit firms provide to the specialist unit can influence specialists' perceptions of the value they add and their contribution to the firm. That is, the capital expenditures incurred to implement a valuation practice impact specialists' perspective of firm support for their work. One specialist characterized valuation as "a very expensive hobby" for accounting firms (P4 Big 4 INTL). Perceptions that firm support for valuation is insufficient can detract from the auditor-specialist coopetitive relationship during the audit of FVMs.

The firm couldn't really give a [expletive redacted] about it [valuations] except in so far as ... [participant omitted details] That's a bit of an exaggeration, but ... I work for an accounting 
firm. We are a small piece of the audit and attest services and tax. We perform some services for them in helping them get comfortable with numbers for their clients. P10 TrienniallyInspected U.S.

The joint output of the coopetitive alliance should increase the firm's ability to compete in the market for valuation expertise (Luo et al. 2006; Menon and Varadarajan 1992). However, coopetition theory recognizes that cross-functional units in a coopetitive alliance have incentives to behave in ways that preserve their self-interest (Arranz and Arroyabe 2008; Czakon and Czernek 2016). The knowledge that the firm both encourages collaboration and still evaluates each unit separately based on its ability to demonstrate its value to the firm drives this opportunistic behavior (Tsai 2002). A key economic issue exacerbating tension between auditors and specialists is feesharing - allocation of a portion of the audit fees to the specialist unit. Specialists believe, overwhelmingly, that auditors are unwilling to share fees with them to compensate for their services even though they charge a lower rate for audit services than for consulting services.

I would negotiate rate and time with an audit partner. I'm not kidding. I literally would be like, "Hey. What's your realization? Okay." I would normally charge $\$ 30,000$ to do this work, but at your realization, I'll take $\$ 20,000$. Here, it's not like that. At this firm, it's, "Gosh, there's no budget. We didn't build it in. It wasn't part of the planning process. It just came up." P21 Triennially-Inspected U.S.

One mechanism that auditors have at their disposal to restrict the portion of the audit fees shared with specialists is control over how to integrate specialists into the engagement budget. That is, auditors can limit the nature, timing, and extent of audit procedures related to specialist usage (Bratten et al., 2013). Specialists report that failure to involve them in the scoping process, for example, detracts from the coopetitive relationship because the specialists' participation in the scoping process has a direct impact on their pro-rata share of the audit fees.

I would say, $4 / 5$ of the time, so $80 \%$ of the time, we're not involved with the budgeting that goes into winning the audit. I think that's even true with the big firms too. They plug in a number. Like, "Oh, it's a $\$ 20,000$ audit. I'll need $\$ 5,000$ of work from my valuation guy." 
Then they come back at the end and kind of cry poverty like, "Next time I'll have you involved." We're not involved. P21 Triennially-Inspected U.S.

When specialists are involved early in the audit, however, it can prevent or at least minimize tensions because the specialist unit can plan and schedule their workflow. Besides, it allows them to develop the appropriate budget for the coopetitive product and fosters a more positive outlook on the coopetitive alliance.

I would say for the better managed tie-in for jobs, that, of course work well, would be a good practice that we will be plotting at the beginning of a session [i.e., audit]. Then we will advise them how much hours we perceive to be using for the valuation's report. Based on our experience, at that time, maybe we can provide better, accurate estimation. P4 Big 4 INTL

Further, specialists believe that failure to include or consult with them early in the audit process when scoping decisions are made can have negative implications for the quality of FVMs because the specialist's input can be critical in determining the appropriate amount of testwork that should be applied to the client's FVMs:

...what ends up happening is when we get selections from them [auditors], we find out that ... you might have things to value that are very simple compared to things that are very difficult, and then you end up with issues on the things that are very difficult. We get into conversations with the audit team over the course of a couple weeks, and come to find out, we as a specialist might have scoped that area very, very differently. P9 Big 4 U.S.

A significant concern arising from auditor and specialist units having incentives to engage in opportunistic behavior that detracts from the coopetitive alliance is that these behaviors preclude the formation of trust between the units (Arranz and Arroyabe 2008; Czakon and Czernek 2016). Tensions over fee-sharing can contribute to specialists feeling that auditors have betrayed them. On the one hand, auditors assert they will advocate for the specialists (with audit clients) to help specialists realize their full billable rate, but then suggest that specialists achieve that rate by using fewer hours. One specialist described this challenge as follows:

In the past there's been some issues where they've written off all our stuff, so for the next year, they've agreed to pay us at an $85 \%$ realization rate. ...Then the next year, they would 
have a conversation with you, which is akin to getting a budget, but not exactly, where they basically tell you, "You can't spend that much time on it this time." P10 TrienniallyInspected U.S.

When auditors impose a short window for the delivery of the specialist's work, it inhibits trust and detracts from the coopetitive alliance. Tensions arise because specialists perceive that auditors' imposition of tight deadlines reflects a lack of respect for their time. While specialists might appreciate that auditors are the dominant group within the audit firm (e.g., Barr-Pulliam et al. 2020), short-notice/last-minute requests to service audit engagements hurt the specialist's ability to generate revenues. Specialists report that the timing around statutory financial reporting deadlines can be an especially economically advantageous window for business opportunities in preparation work because they charge a premium for non-audit clients with tight deadlines. This heightens the "opportunity cost” of providing evaluator services at lower realization rates and detracts from the coopetitive relationship.

More concerning is that specialists perceive that the "fire-drills" associated with unrealistic demands for specialists to perform represent a significant threat to audit quality and, ultimately, the quality of the FVMs that appear in audited financial statements. One specialist revealed that deadline pressures have negative implications for the quality of FVMs because, at that stage, auditors adopt the approach of “What little can you do to tell me everything's okay?” (P21 Triennially-Inspected U.S.). The auditor-specialist relationship becomes strained when specialists respond to this pressure by (deliberately) limiting the scope in their report, which displeases auditors. One specialist described the back-and-forth:

It kind of becomes this tug-of-war where my team will attempt to limit their scope to protect their own credentials, but then the audit partner looks at it and is like, "This isn't good enough." P21 Triennially-Inspected U.S. 
Specialists expressed concerns about extracting an appropriate amount of resources from the coopetitive alliance that is in line with their self-interest, which appears to drive their perceptions of auditors. Worldwide, specialists indicated that discussions with auditors over their service fees pose threats to their coopetitive relationship that extend to the quality of the FVMs.

It also depends on what budgets they've agreed with the client. If they've agreed to a small budget, and we come up, and we say, "We'll do this for you, but it's going to cost you $£ 10,000$." Then auditors are like, “No.” We can’t even charge them for the full order; we can't charge for just one instrument. In times like that, we have to do as little as possible, but be able to give them the necessary comfort. P6 Other Annually-Inspected INTL

A gap exists [between specialists and auditors' understanding of what it takes to perform a valuation]. [It] is [like] a gap that exists between ... a contractor and a homeowner. The homeowner wants it done fast and cheaply, for obvious reasons, and the contractor has to do it the way he or she can do it, and it costs what it costs. P3 Big 4 U.S.

On the other hand, some specialists seem to appreciate that the intra-firm alliance (Peng et al., 2012; Ritala 2012), despite the competing unit-specific incentives, can provide global gains when the audit firm's brand and resources are elevated. Thus, these specialists report that they push back against pressure from auditors to satisfice on their audit support responsibilities. Nevertheless, they reconcile two motivations in balancing their incentives versus responsibility to the audit firm as providers of audit support. First, they see no benefit in fighting with auditors because providing additional work does not increase the specialist unit's bottom line. Specialists refer to audit support work as "inside sales with no credit." Second, related to group identity (discussed later) and the salience of the specialists' collective identity, specialists are motivated to protect the audit firm by ensuring that the testwork performed for the audit client is sufficient (i.e., they challenge auditors' scoping judgment).

I have a client where I'm asked to look at ABC, but I have all the financials. Then I go back to the audit partner, and I'm like, "Hey. Did you think about this? Is this an embedded derivative? Is this a contingent consideration?” I'm raising to the audit partner valuation things to consider because it's almost like inside sales for me. Here, the way the incentive structure is set up is it all goes to the credit of the audit partner. So, if I raise the awareness 
around a valuation matter, again, protect the firm first. So if I think it's a problem, I'm going to raise it up. [But] I'm not going to go scratching around because there's no upside for me. (emphasis added) P21 Triennially-Inspected U.S.

While auditors might not be able to constrain the amount of time specialists dedicate to audit tasks in their dual roles, specialists report that they feel pressure to provide evaluator service at even lower costs because "pressure is coming from people who are senior to you, so you end up just working time for free [i.e., eating time]. It’s just the way it usually works.” (P10 TrienniallyInspected U.S.). Prior research that finds discouraging disagreements in cross-functional teams can negatively impact performance (Lovelace, Shapiro, and Weingart 2001), if specialists cannot withstand partner pressure, there is an increased risk that they generate valuations to meet the partner's preference rather than applying the best approach to fit the facts and circumstances.

Consistent with their appreciation of the advantages of being associated with a brand-name audit firm, specialists perceive a key benefit of role duality is an enhanced ability to gain non-audit work. This enhanced opportunity to acquire non-audit clients due to audit firm membership is attractive to the specialist unit because it makes them less economically dependent on audit support work (fees). We observed that the specialists who focus on the benefits associated with their dual role perceive that it enhances the coopetitive alliance and reduces tensions in the coopetitive relationship with auditors. These specialists also appreciate that role duality brings opportunities to see the types of products and valuation methods used across the firm's portfolio of audit clients. Specialists value such exposure because it sharpens their skillsets and increases their knowledge of the audit process and its idiosyncrasies.

I do think that it's helped [i.e., performing audit support and consulting]. I have a unique seat...because I am a dual expert on the accounting side, as well as run our valuation audit support at our national securities center. So I get to see both sides [and] that has helped over the years. P9 Big 4 U.S. 
The reason why we are doing this is it will allow us to stay in the market. We will be able to understand what kind of products are important products in the market and the kind of instruments that they find interesting, and things like that. It is a way to keep ourselves updated. P6 Big 4 INTL

Other specialists had positive perceptions of audit assist work because they enjoyed the nature of the work and that it did not require marketing services externally. These specialists appreciate that being a member of the audit firm means that auditors (i.e., internal clients) come to them to request their services. Some specialists also enjoyed the challenge of interpreting and applying the fair value accounting standards and regulations to CFIs. Thus, while less profitable, segments of the valuation specialist population prefer the audit assist role because they find the work to be interesting and require limited interactions with external clients, which can influence their perceptions of the coopetitive alliance.

But there are a lot of new hires we get that don't want to go help a big company overhaul their valuation process. They want to do technical accounting work, and that stuff is not overly profitable. Those are the people that actually spend time assisting the audit practice because that's where the technical accounting work is, so I think it goes both ways. P9 Big 4 U.S.

For some specialists, an imbalance in roles, that is, more time on audit assist relative to non-audit services can induce stress because effort allocated to attaining the coopetitive product (auditor's goals) subverts the availability for effort on the specialist's goals. Research suggests this stress from role imbalance can detract from the coopetitive relationship (e.g., Tjosvold et al. 2003; Johnson et al. 2006). Specialists perceive the economic impact of providing evaluation services could best be measured in terms of limitations it imposes on the number of external projects they can accept while continuing to meet their audit engagement demands. In some firms, specialists noted that being dedicated in their work with auditors and educating auditors on the specialist's role has helped to improve the coopetitive relationship because “...over time, structures were put 
in place, albeit far from perfect, ... [which had] a massive effect on freeing up people's time to focus on external [non-audit support] work.” (P5 Other Annually-Inspected INTL).

Our interviews yield that one group of specialists, "hybrid specialists," face greater economic pressure in balancing both evaluation and non-audit services. As noted in our discussion of organizational structure, some audit firms specialized group of hybrid specialists comprised of professionals who have significant audit and valuation expertise, and these specialists serve as intermediaries between the two coopetitive units. These hybrid specialists appear to have a strong concern for the quality of FVMs and maintaining a positive coopetitive relationship. Even when economic pressures might force them to prioritize the more lucrative consulting projects, they report working outside of regular working hours to fulfill their audit-support responsibilities:

...95\% of us who are hybrid specialists...actually work within our advisory practice. We don't work in audit, so there they pull on our time... [preventing us from being] focused on consulting projects. What ends up happening is that the services that I provide to an audit team, while it's intended to be risk management, ends up being night and weekend work... P9 Big 4 U.S.

Further, it appears that serving in the hybrid role imposes personal stress on specialists. They report that specialists who spend more time assisting auditors are perceived as being in a less prestigious service line because the audit assist role can be seen as less 'tech-savvy' than consulting work. To avoid this negative perception, hybrid specialists respond by prioritizing non-audit work and relegating their audit support duties to times outside of the normal workday.

[T] here is a view from some of my counterparts that those people who are serving as dual specialists are disadvantaged because there's only downside. Because we have counterparts that maybe are focused on technology that aren't derivative experts or revenue experts. They don't have these ["hybrid"] responsibilities, so they can just focus on their consulting project, so I think that's the real ... When you get to the heart of it, that's the real issue about the push and pull and why it [audit support] becomes night and weekend [work]. P12 Big 4 INTL

Having hybrid specialists place a lower priority on audit support has negative implications both for the coopetitive alliance and for the audit firm. Auditors are apt to resent specialists treating 
their engagements as second-class projects, and therefore frictions in the coopetitive alliance can ensue. Treating audit-support assignments as second-tier is likely to impair FVMs audit quality and increase audit firm risk. Further, consistent with research that employee stress and organizational commitment are negatively correlated, the personal stress that hybrid specialists experience in balancing their evaluation and consulting roles could threaten their commitment to their employer and, perhaps, to the profession (e.g., Wiener 1982; Sullivan and Bhagat 1992).

\section{Project Goals}

Coopetition theory holds that a lack of common understanding and conceptualization of shared goals contribute to tensions, which can lead to unhealthy coopetitive behavior(s) (Fernandez et al. 2014; Dahl 2014; Luo et al. 2006). Dahl (2014) finds that conflicting goals within an organization increase coopetitive tensions. Fernandez et al. (2014) find that when units in a coopetitive alliance hold incongruent conceptualizations about the coopetitive project and expectations of the project outcome, it produces tensions across teams and reduces cooperation. Luo et al. (2006) find that reduced cooperation among teams is detrimental to firm performance. Our interviews reveal that differences in the definition and conceptualization of the valuation task, perceived goals, and project outcome contribute to tensions in the auditor-specialist alliance.

The extreme estimation uncertainty around FVMs presents a significant challenge that auditors perceive inhibits their ability to provide reasonable assurance that the client's FVMs is fairly presented (Hilton and O’Brien 2009; Choudhary 2011; Christensen et al. 2012; Cannon and Bedard 2017). Auditors tend to be ambiguity averse, preferring to gather audit evidence that is well-defined, easily verifiable, and that can reduce uncertainty. More precise and clear-cut results appear to give auditors greater comfort that their conclusions are based on persuasive audit evidence (e.g., Luippold and Kida 2012; Joe et al. 2017). 
Auditors are also bound by standards that require a conclusion as to whether the financial statement balances are presented fairly in all material respects (AS 3101, PCAOB 2017). Consequently, it is not surprising that they view materiality as a key factor in the task definition of the coopetitive project and tend to be goal-oriented towards more verifiable and well-defined point estimates. In the specialist's view, however, the nature of FVMs for CFIs is such that a point estimate would be inappropriate due to the wide range of and inherent subjectivity in valuation inputs. Specialists argue that there is no "precise valuation" for many financial instruments. They are cognizant that slight variations in some model inputs and assumptions can lead to significant variations in the FVMs, even though the alternative values could still be considered appropriate estimates. These conflicting views on task definition and the coopetitive project goal represent a key point of contention between units that threaten the strength of the coopetitive alliance. Participants characterized the issue as follows:

It's difficult because the audit mentality is you're looking at a point estimate.... My point of view, there's always going to be a range. The question is...how far off is enough. P1 Other Annually-Inspected U.S.

It's when the number's outside the range that they [auditors] have problems with, because again, they're trying to get to a number. What's interesting is, I've had recent run-ins with my old peers where I'm a third-party valuation specialist [for the non-audit client] and [Big 4 Firm name redacted] is the auditor where they want my number to land right on top of theirs. The auditor wants it to be precise within the dollar on these really esoteric Level 3s. Well that must be some kind of new policy because ... It's a reasonableness test, not a 'I-get-tothe-same-number' test. (emphasis added) P21 Triennially-Inspected U.S.

That's where I think we run against... this notion of valuation uncertainty. Where there is a wide range of prices that are representative of fair value and our audit team is like, "Well, our materiality is a third of that, and we can't have this range," so there is some tension. P8 Big 4 U.S.

Auditors and specialists also think differently about the initial starting point and how to determine the scope of the coopetitive project. Specialists assert that their preferred starting point is an evaluation of the client's valuation methodology and approach. Specialists disagree with 
auditors, who prefer first to determine the materiality of management's FVMs. Specialists perceive that the auditors' approach is flawed because auditors assess materiality relative to the FVM amount reported by the client. However, specialists believe that an evaluation of management's approach to the FVMs is necessary before one can determine that the value produced by that approach is reasonable relative to materiality. These conceptual differences can contribute to tensions across the two cross-functional units.

I think you're always looking at is the value itself reasonable? Sometimes the audit team is trying to scope out beforehand whether you should review it...They're looking for... if its below materiality or if it's a publicly-traded instrument, they would say it's a low risk of a value. P1 Other Annually-Inspected U.S.

... We found that what the client was doing was, again, fundamentally wrong, but ... we got extreme push back from the audit team, to say that's not an error for us [because] even though it’s a significant amount, it doesn't breach materiality. P21 Triennially-Inspected U.S.

Our discussions with specialists reveal that tensions over the starting point and outcome from the coopetitive alliance can be mitigated when specialists are more aware of the challenges that imprecision around the valuation range can pose for auditors' even if specialists believe the range is “acceptable from a valuation angle” (P18 Big 4 U.S.). For example, some specialists report conducting a range of sensitivity analyses that "smooths any major differences" between specialists and auditors (P18 Big 4 U.S.). Coopetition research finds that shared understanding improves coopetitive outcomes (Fernandez et al., 2014). Consistent with these findings, some specialists perceive that helping auditors to understand how valuations are determined, as well as the underlying reasons for the valuation range, can enable auditors to navigate the measurement uncertainty inherent in the valuation process and reduce tensions in the coopetitive alliance.

At least within [Firm name redacted], I think we've reached a détente with the audit practice as it relates to the valuations of, I would say, probably $90 \%$ of instruments that we touch. By that, I mean, I think they understand how we deal with valuation uncertainty, how we create our ranges, but where we, I think, probably have some challenges is primarily in the 
distressed and certain other instruments that are highly sensitive to small changes or inputs. (emphasis added) P8 Big 4 U.S.

I think it really comes down to the auditor's experience and if they're introduced to valuation probably more when they were staff and understand the dynamics that generally happen... That's something that comes from more education and more understanding of valuation... P2 Other Annually-Inspected U.S.

Specialists consistently noted that auditors' lack of appreciation for and understanding of the full complexity and nuance of FVMs detract from the coopetitive alliance. They generally perceive that auditors "underestimate what they think the work involves” (P12 Big 4 INTL), which leads to a "check-the-box" audit approach for FVMs and the decision to engage specialist support. Although this check-the-box mentality can frustrate specialists, they seem sympathetic to the demands of auditing. Some acknowledged that the magnitude and variety of knowledge auditors need to integrate seems to exceed reasonable expectations for a single professional group:

I think there's kind of a Peter Principle where you kind of rise to your highest level of incompetence. The role of the auditor is such that they almost shouldn't be good at what we do. I hate to say it because then you wonder how distracted are they in regards to tax matters... other SAS-70 type processes, or IP security? If you're an auditor, frankly to me, the definition of that is somebody that looks at a number and develops a workpaper set that demonstrates that's a real number. P21 Triennially-Inspected U.S.

Specialists perceive that a "check-the-box" audit mentality exacerbates tensions in other ways. For example, when auditors adopt this approach, they tend to involve their specialists at the last minute. As discussed earlier, last-minute audit support requests frustrate specialists because they create unrealistic deadlines, unnecessary time pressures, and preclude specialists from providing valuable counsel to the audit team throughout the audit engagement. Timelier engagement of specialists allows them to help resolve issues as they arise rather than in a "firedrill" mode at a late stage in the audit. One specialist indicated, "the biggest impasses are those that didn't involve us in the kickoff calls to discuss proposed methodology, and that's where the biggest issues arise” (P2 Other Annually-Inspected U.S.). Consistent with Padula and Dagnino’s 
(2007) findings that tensions arise when collaborating partners pursue conflicting interests, specialists perceive that auditors involve them at the last minute solely to "check-the-box" that the audit team consulted a specialist. Specialists perceive that auditors disregard ensuing challenges that engaging them late poses to an effective FVM evaluation.

"We would get some work that needs to be valued as soon as possible because they're close to the deadline or something like that, and it's like, 'We didn't know we had this.”' P17 Other Annually-Inspected U.S.

Relatedly, specialists perceive that auditors are overconfident in their abilities to complete the fair value audit without specialist involvement. Specialists perceive that this contributes to tensions associated with time pressure imposed on the coopetitive alliance. Prior research suggests that auditors' overconfidence in their abilities, and the abilities of others, can have deleterious effects on auditor judgment, especially for more difficult tasks (Kennedy and Peecher 1997; Han, Jamal, and Tan 2011). Several specialists report receiving urgent (fire-drill) requests for audit support due to auditors "basically just trying to do it on their own" but then being forced to engage specialists "when the audit is going through final review by our professional practice group. [At that point] it’s like, 'We're trying to get this out'?” (P10 Triennially-Inspected U.S.). Specialists report that time pressures inhibit their ability to perform valuations competently and can pose a threat to their professional license and code of conduct. One specialist framed the issue as follows:

I can't tell you how many times I hear them say, "Well, I used to do valuations, so I know how to do it. Blah, blah, blah. But I'm just calling you to make sure everything's okay." Right? It's very nice of you to put my accreditation at risk. Thank you. P21 TrienniallyInspected U.S.

Some specialists perceive these auditor-imposed time pressures reflect auditors' lack of respect for the specialist's reputation and the effort specialists exert to evaluate FVMs. In some circumstances, specialists withhold cooperation, retaliate by pushing back on auditor demands and reducing the level of assurance in the valuation report, and or issue valuation reports with caveats 
(which they know auditors do not want). Griffith (2020) documents that specialists include caveats in valuation reports to limit responsibility and communicate reservations. Specialists' caveats typically force auditors to perform additional follow-up audit procedures, which heighten tensions between auditors and specialists. While specialists pool their resources with auditors to achieve the shared goal of providing audited financial statements to the client, they also strive to protect their autonomy and reputation in the market through providing high-quality valuation work (Gnyawali and Park 2009; Barr-Pulliam et al. 2019). Several specialists we interviewed expressed, “we are not going to give you [auditors] a conclusion if we don't have the right amount of time" (P12 Big 4 INTL). This response signals how tensions in the coopetitive teams can drive behaviors that can threaten the parent firm's performance and reputation.

Competition in the audit market means that auditors must balance the tradeoff between performing audits to manage the business and audit risk as well as meeting user expectations and regulatory oversight versus maintaining a positive relationship with the client (e.g., Glover et al. 2019; Bratten et al. 2013). Risk of client loss and incentives to please the client motivate auditors to accept client-preferred accounting treatment when standards lack precision and guidance is vague (e.g., Farmer, Rittenberg, and Trompeter 1987; Hackenbrack and Nelson 1996; Kadous, Kennedy, and Peecher 2003; Cannon and Bedard 2017). Cannon and Bedard (2017) find that although disagreements between auditors and the client are commonplace with complex FVMs, auditors propose relatively few adjustments. Our interviews provide further context to their results. Several specialists perceived that auditors were hesitant to support their specialists when the client opposes the proposed adjustment to bring their FVMs in line with the specialist's valuation. ${ }^{9}$

\footnotetext{
${ }^{9}$ We provide illustrative quotes from participants in the paper from specialists employed by Bi4 and Non-Big4 firms and domiciled across all the regions of the globe. These sentiments were common across all specialists and we noted no cross-sectional differences in sentiments in the full sample of participants.
} 
Specialists' perceive that auditors are quick to acquiesce to client preferences, and this perceived acquiescence could be a significant source of tension that undermines the coopetitive alliance. Specialists perceive that auditors' deliberations with clients focus more on "client happiness" and that 'auditors don't' like to get a situation where we're telling the client that they have to have the valuer redo it” (P3 Big 4 U.S.).

The audit-team is very sensitive to the audit relationship. And right or wrong has nothing to with it. If you're jeopardizing an audit relationship, it doesn't matter ... because it's always going to be important to the team involved. That's the third point of tension. P3 Big 4 U.S.

Specialists believe that the pressure on auditors to maintain positive client relationships can also result in last-minute evaluation projects that exacerbate tensions between auditors and specialists. As specialists see it, clients often do not want to fair value some of their financial instruments because they do not want to incur the associated fees on two fronts. The first concerns hiring a third-party specialist to assist them in the preparation of the FVMs, and the second concerns increased audit fees to cover the auditors' use of their specialists. Specialists expressed frustration that to avoid souring the auditor-client relationship. Auditors will initially bend to management's pushback about the necessity to fair value the account and then subsequently demand a last-minute specialist when the audit quality control reviewer forces the issue.

Then the accounting rules come along, and they will say: "Actually, you need to fair value this," but the client has got very little interest, and the audit team can be kind on their side a bit... Sometimes that can be a little bit of an impediment towards getting to the right answers as quickly as possible. P12 Big 4 INTL

Retaining specialist's support at the last minute creates tensions, not only due to the time pressures on the specialists but also due to conflict with the client when the auditor notifies the client of an audit fee increase due to the use of the specialist. Specialists contend that auditors' concerns over fees and profit margins contribute to auditor angst as auditors "hope...that the client 
agrees” (P12 Big 4 INTL) with fee changes attributed to last-minute evaluation of FVMs. Further, specialists suggest that the pressure on audit margins and the "commoditization" of the audit leads auditors to underestimate and underweight the risk that FVMs pose to the audit when they focus on maintaining client satisfaction and minimizing conflict with the client.

I think we're going to see more fire-drills, and I think that that creates risk because if somebody's issuing a convertible [i.e., a high-risk client], they're pretty far down on the credit curve anyway [engaged in high credit risk transactions], right? P9 Big 4 U.S.

I will say the propensity of the auditors here to defend the clients, almost as if they're on that side of the table. When I'm raising a valuation matter, that is where it's frustrating. I don't think it's so much a competence, as more of a business risk of, "well, you know audit partner"...I bring this up to you because here's the risk. When something is obviously wrong, and the audit partner is like, "Well, we signed off on it last year, even though I wasn't here," or, "I think it's good enough.” Don't call me! I would say I don't think it's a competency issue. I think it's almost like the [client] alignment because auditing is so commoditized, and there's so many people out there just waiting to be like, 'How satisfied are you with your service? You guys are fired. You guys are hired.’ P21 Triennially-Inspected U.S.

Prior research finds that regulatory inspections prompt auditors to be more cautious (e.g.,

Johnson, Keune, and Winchel 2019; Westermann, Cohen, and Trompeter 2019; Cohen, Joe, Thibodeau, and Trompeter 2020). Consistent with this research, specialists indicate that the risk of regulatory scrutiny on audit engagements mitigates the likelihood they would delay engaging the specialist at such a late stage that would run the risk of damaging the relationships with specialists. ${ }^{10}$

There are a lot of times where we get a request to review a convertible preferred stock issue, and that's pretty complicated for a technology company four days before you're supposed to sign the opinion and come to find out that stock issuance was done eight months ago. That doesn't happen often on the PCAOB engagements. P9 Big 4 U.S.

\footnotetext{
10 Barr-Pulliam, Joe, Mason and Sanderson (2019) interviewed specialists who both prepare initial FVMs for management and assist auditors in evaluating the reasonableness of FVMs. Their findings suggest that specialists often interact with PCAOB inspectors, with or without the audit team present, during the onsite phase of the inspection to answer questions about their work on FVMs. Neither interviewee suggested that specialists assume reasonability for inspection-related audit failures or otherwise. In our discussion of Group Identity, we note that specialists perceive that some auditors attempt to absolve themselves of responsibility for any judgments related to the coopetitive product.
} 
Our discussions revealed that there are at least four moderating factors that can affect tensions around the auditors' approach to engaging the specialists. First, specialists report that even when the need for valuation expertise on a recurring audit is known, engaging the specialist might still be delayed due to the loss of knowledge when there is auditor turnover each engagement period. Consequently, there can be inadequate prioritization of valuations on the audit:

Yeah, you still find that they will be quite late in coming. Even if it's one that you know happens every year, because the auditing seems to change quite a lot. They don't always seem to be fully informed that they need to get the valuations done. P6 Other AnnuallyInspected INTL

Second, specialists believe that auditors who lack experience in performing audits of FVMs are more likely to have difficulty managing their client's expectations and delay engaging specialists, which contributes to tensions in their relationship:

The partner wasn't very helpful, and I think didn't understand the issues that ... and I think the fact that we were trying to do the whole thing in about two days really didn't help. We had a client that turned around to say, "But you haven’t raised this before now," and I think that's always a difficult scenario. P11 Big 4 INTL

Third, specialists contend that their assessment of the competence of the client's third-party specialist (professional preparing the client's FVMs) influences the time and effort specialists expend evaluating the client's FVMs. Specialists observe that when they unexpectedly discover that the client's third-party specialist is inexperienced, it requires more time to complete their due diligence. This unanticipated time increase can frustrate auditors and exacerbate tensions between the two units over the specialists' time and fees billed to the audit engagement.

It just depends naturally on who that third party [specialist] is. If it's a smaller firm, where perhaps they're not experienced, the first response of the audit team can be they've valued the wrong thing, or they're missing a fundamental. Then it can spiral into a very long process. When we're giving audit teams a quote... for our time, it's very heavily caveated because it's just an unknown, at the end of the day. P5 Other Annually-Inspected INTL 
Last, we find that the specialist's attitude can contribute to tensions in their collaborations with auditors. While some specialists appear to accept and have a tolerant attitude towards the time pressures that auditors impose on them, other specialists seem dismissive and push back on lastminute demands from auditors. Likely, such specialists' attitudes will escalate tensions in the coopetitive alliance. One specialist shared:

...One of the young people will come to me and say, "The audit team has said they need this Friday, and it’s Wednesday.” I tell them two things, because it's part of my job to mentor them. I say, "First of all, they don't know the difference between need and want, they want it Friday. And secondly, please let them know that I want a house in Beverly Hills. And I had been wanting it for a very long time, but so far it hasn't happened.” P3 Big 4 U.S.

\section{Group Identity}

A salient collective group identity enhances healthy coopetitive relationships and fosters productive cooperation on teams (Willer 2009; Bauer and Estep 2019). Willer (2009) finds that group identification helps shape members' priorities to focus on the well-being of the collective,

even in the face of personal sacrifice that can jeopardize personal benefits. Similarly, Bauer and Estep (2019) find that when auditors and IT specialists share a strong collective team identity, team communication and coordination of activities is enhanced. Focus on the common group identity creates opportunities for the collective goal to supersede the goals of the individual units, which, in turn, improves cooperation to the benefit of the collaborating team (Gottschalg and Zollo 2007). Downey and Bedard (2018) find that tacit coordination factors like leveraging common ground and increasing group cohesion could positively influence decision-making in group audits.

In the auditor-specialist alliance, specialist's perceptions that auditors view them as a valuable part of the team enhance the specialists' cooperation and satisfaction with the coopetitive alliance. Specialists indicate that when "the audit team is on your side...and understand where we're coming from, it's a lot smoother [valuation] process” (P9 Big 4 U.S.). Importantly, we 
observe that it was not only being seen as a team member but also the specialists' desire to be valued for the expertise they provide in audit evaluations that enhance their collective identity and satisfaction gained from the coopetitive alliance:

...our teammates must see the team expertise we have in this area, and so this is also the perception that we have quality in our team... I think, the most rewarding experience...is that we're recognized as the true gurus in the field. I think my team has gained a very good reputation among, even within the __ [redacted] firm... They recognize this team is really sophisticated and capable team. I think this is one very important incentive for the team to work. P4 Big 4 INTL

Barreto and Ellemers (2002, 636) find that collective group loyalty is enhanced when individuals are "treated in ways that communicate respect." Perceptions of being respected by the members of one's group improve group cohesion, coordination, and performance (Barreto and Ellemers 2002). In the auditor-specialist alliance, specialists seem to interpret the extent to which auditors become actively involved in the valuation process as an indicator of auditors' respect and value for them as partners. When specialists perceive that auditors have a vested interest in working with them as partners to identify and resolve valuation issues, it builds a more collectivist approach in the coopetitive alliance, and specialists reciprocate by engaging in more cooperative behaviors. For example, specialists become proactive in reaching out to auditors to preempt conflict over lastminute issues, and they help to build auditors’ knowledge about valuation:

...We became a lot more proactive in just reaching out to the audit teams, six months ahead of the year end to say, 'Even if you think nothing's changed, let's just have a chat, and let's talk things through, so that we don't end up with last minute problems,' which has really helped. P11 Big 4 INTL

I did a training for the audit team and noted this effect on valuation issues. This is not something valuers were doing naturally, which requires a lot of time to prepare. This was very informal, and this was really, 'You work with us all the time, we have this question, let's work together and answer them.'... I see more coming in the future, that we are more integrated, and we are working together, and we are answering the clients as well together. P18 Big 4 INTL 
Raza-Ullah, Bengtsson, and Kock (2014) explain that coopetitive teams experience tension when team identities are mixed but not merged to form a collective unit. The internal conflict and the psychological disequilibrium that team members experience when there is a low sense of collective identity produce conflict in the coopetitive alliance. In the auditor-specialist alliance, specialists indicate that when auditors disengage from the valuation process and when specialists feel they are treated as "outsiders" rather than team members, there is disassociation, which inhibits cooperative behaviors. Specialists express frustration when auditors are uninterested in participating in the valuation process - "Most of the audit teams I work with are not talking with the valuers, or even the clients themselves because they don't really want to get involved" (P6 Other Annually-Inspected INTL). Specialists share the sentiment that sometimes, audit teams view the evaluation of FVMs as being "outsourced" to the specialists, making them absolved of valuation responsibility and justified in their disengagement:

I think often audit teams think, 'Well, we've outsourced this, so we've outsourced the whole thing and the responsibility, and therefore it's for someone else to pay attention to what's going on, and discuss it with the client and get it resolved.' That would be my observation. P11 Big 4 INTL

Interestingly, the specialists who were once former auditors seem most disturbed by the lack of auditor involvement in the valuation process. These specialists seemed almost hurt by their former peers and shared heightened feelings of frustration that the audit team did not embrace them:

I think that sometimes in our firm, audit teams don't understand the specialists are also auditors, so clearly... when we involve tax specialists or pension specialists, they are not auditors, but our financial instruments specialists are all auditors. I think that it helps, but it does definitely cause a lot more frustration in the specialists. That means for myself, because ...It's almost awful for me to think that the standard on that [i.e., another] audit would be very, very different to the standard on my audit. And it's disappointing that as a firm, our standards are not the same. It is extremely frustrating. P11 Big 4 INTL 
Earley, Brown, and Sanderson (2020) find that the engagement partner's attitude sets the tone for the audit team. Specialists similarly describe how the audit partner's attitude influences whether the team adopts more collectivist views, whereby they engage specialists earlier.

They [auditors] don't want to engage with you... so if they have to, the attitude from the partner down can be very dismissive. P5 Other Annually-Inspected INTL

Nevertheless, just as the audit partner's attitude can hinder building a collectivist identity to promote greater cooperation, some specialists had a strong view of their professional responsibility and were motivated to collaborate. These specialists seemed to value the contribution they make to the firm, as a whole, and to the production of a higher quality audit. Prior research finds that a collectivist approach improves team members' propensity to collaborate and motivation to work hard towards a common goal (Weingart and Jehn 2000):

I...ultimately take the view that, even though you're a specialist, and to some extent audit teams might think they've outsourced to you, you are actually fundamentally delivering an audit as an audit firm, and the fact that you use internal specialists, is kind of neither here nor there. You are ultimately just trying to...deliver a good audit. P11 Big 4 INTL

\section{Knowledge Sharing}

Knowledge sharing can strengthen coopetitive relationships and enhance the joint product of the alliance. Prior studies highlight that the inherent value in cross-functional teams arises from the inter-team coordination and sharing of knowledge and expertise in a manner that synergistically enhances the coordinated output (Hong and Vai 2008; Love and Roper 2009). However, each team's knowledge represents an idiosyncratic resource that is the basis of the team's competitive advantage in the coopetitive alliance (Lorange 1996; Van Der Bij, Song, and Weggeman 2003). There are strategic incentives to protect proprietary knowledge, which deter or cause incomplete knowledge sharing, and can increase tensions in the coopetitive alliance (Loebecke et al. 1999; Luo et al. 2006). 
Specialists have strategic incentives to protect their valuation knowledge as it is the basis of their economic subsistence in the firm and undergirds their ability to generate future revenues from both audit and non-audit clients. As a result, specialists are cautious about sharing information about their proprietary methods and models with auditors due to the risk that it could threaten their economic viability. We find that specialists' willingness to share knowledge (e.g., valuation models) depends on whether they trust that auditors will not misuse the information in a manner that imperils the specialists' future revenue generation potential. Prior research finds that trust "is at the heart" of knowledge sharing (Davenport and Prusak 1998, 35). High levels of trust are essential to effective communication (Dodgson 1993) that "facilitates the sharing of...knowledge” (Ichijo et al. 2000, 200). Pratt and Jiambalvo (1981) find that mutual confidence and trust among team members directly enhances audit team performance. Further, Bills et al. (2020) find that trust is a strong relational mechanism that encourages collaboration and mitigates tensions in the coopetitive alliance.

We note that key attributes of knowledge sharing in the auditor-specialist coopetitive alliance are particularly interrelated with the associated economic dependencies and stressors. Specifically, specialists do not trust that auditors have 'pure' intentions with valuation information, and this lack of trust inhibits effective knowledge sharing and heightens tensions in the alliance. In addition, such distrust arouses suspicions that auditors will engage in activity that undermines and exploits the specialists' interests (Weingart and Jehn 2000; Bills et al. 2020). Specialists perceive that if they share their valuation knowledge and models, auditors will misuse the models by running the same model on subsequent audits and, as a result, not seek or restrict the amount of specialist support on future engagements. In this way, specialists' reluctance to share information may be a competitive response to protect the provision of valuation services from 
auditor encroachment on what they perceive as their professional jurisdiction (e.g., Griffith 2020).

Consequently, the specialist's unwillingness to share valuation information with auditors can exacerbate tensions between the teams.

We will never, ever share our models with them [auditors], because what we found in the past, is they will, in the next year, they will just use your model themselves, with no idea of how to actually apply it correctly... They will just email us and say, 'Last year you sent us this model, can you please give us a new assumption, so we can apply it on this model again?’ Then we're like, 'Something's going wrong here.' P6 Other Annually-Inspected INTL.

Not only do specialists distrust auditor use of their models on subsequent engagements, but specialists also perceive that auditors will inappropriately share their models with audit clients. Specialists shared that, "with absolute certainty, 100\% of the time, if you provide a live model to an audit partner, that partner will provide it to their clients” (P21 Triennially-Inspected U.S.). Interestingly, even though specialists cannot prepare FVMs for audit clients, they demonstrate professional allegiance to protect the market for FVMs preparation service and ensure that the market, as a whole, is not economically restricted.

Erosion of specialist trust and reluctance to share information in the auditor-specialist coopetitive alliance can lead to negative consequences that impair the quality of FV audits. Even though the specialists express reservations around sharing valuation models with auditors and appear to feel justified in their decision, they acknowledge a potential fallout from this action. One specialist recounted an example where, due to auditors' inability to access valuation models from the specialist team, auditors unilaterally obtained valuation models from the internet in an attempt to analyze the valuations themselves without specialist support or input. These risky auditor actions could lead to inappropriate FVMs evaluations and undermine the quality of the audit:

Some of them [auditors] will still go, if it's a normal Black-Scholes formula, they will try and find it on the web, and try and make the share awards fit into that model, even if they 
don't. Yeah, that's an argument we have, also, quite a lot of the time. P6 Other AnnuallyInspected INTL

Specialists lament that in instances when auditors attempt to perform valuations themselves, auditors eventually have come back to the specialist for audit support quite late in the process because auditors are "not competent on their side" and are "not capable of forming [an] opinion about value on these securities or positions” (P3 Big 4 U.S.). These late consultations lead to contracted review schedules for specialists and contribute to tensions in the coopetitive alliance. Further, auditors' perceived lack of valuation competence and appreciation for the valuation process has, in specialists' views, broader implications for the audit of FVMs and auditors' ability to assess the client's valuation processes. One specialist shared concern that:

...based on some of the benchmarking work we've done... where we've advised some large complex [valuations], they [auditors] might want to make changes. It does give me a little pause about the work and the understanding that their external auditors do have around their valuation process ... Given some of the things that we see, it might call into question: why there hasn't been some sort of control weakness ... that [rises] to SD [significant deficiency] or MW [material weakness] where you'd view it publicly? P9 Big 4 U.S.

Notwithstanding the competitive advantage that knowledge individually presents to each team in the coopetitive alliance, sharing knowledge across teams can ease coopetitive tensions and stimulate superior performance for the firm as a whole (Luo et al. 2006). As a result, knowledge sharing across auditor and specialist teams can enhance the collective team's ability to convert tacit knowledge into value for the client and the firm (Ghoshal, Korine, and Szulanski 1994). Specialists acknowledge that they are uniquely positioned to improve auditors' valuation knowledge and play a vital role in upskilling their auditor colleagues. They recognize that sharing information with the audit team is a reinforcing behavior that fosters a positive relationship with auditors and, in turn, facilitates greater knowledge sharing between the teams.

I've always thought it a responsibility of the specialists to help in the upskilling of the auditors. P11 Big 4 INTL 
Yes, definitely [we will educate auditors about valuation]... "Look, this is what is going on here. These [are] the sensitivities, and this is what needs to happen.” And then ... deciding whether this is something that we need to talk directly to the client [about], which we do a lot more of than say we would have done even a few years ago; or if it's something that the audit team can get a quick trip back to the client and sort out.” P18 Big 4 INTL

Further, specialists recognize that while it is important for auditors to know about valuation

processes, it is also important for specialists to obtain knowledge of auditing processes better to serve the auditor as a client. Specialists agree that sharing knowledge across members of the auditor-specialist alliance enhances the quality of the audit product and benefits the firm:

All of our specialists now are audit trained individuals. I think that does help us a little bit in helping them to understand what audit teams need...Y You ultimately are just trying to build a team of people with the right skills and knowledge to deliver a good audit. P11 Big 4 INTL

\section{Conclusions and Implications for Research}

We examine the perceptions of audit firm-employed valuation specialists to understand how they work with auditors when evaluating the reasonableness of audit clients' FVMs. Specialists are increasingly vital to the audit as auditors typically lack requisite valuation knowledge and or expertise to audit FVMs. However, the specialists’ perspectives and insights on how the factors that influence their collaboration with auditors affect their valuation reports and the quality of FVM audits are mostly absent in the literature. Thus, together with the prior literature focused on auditors' perspectives, our examination of specialists' perspectives of the sources of tensions in the auditor-specialist alliance allows for a complete understanding of how the efficacy of the alliance impacts fair value audits and financial reporting. We use the intra-firm perspective of coopetition theory to develop a framework that analyzes specialists’ perceptions of the auditorspecialist relationship, and its implications for FVMs. Our discussion focuses on five factors that contribute to or diminish tensions in the coopetitive alliance: organizational structure, economic independence and stressors, project goals, group identity, and knowledge sharing. 
We base our analysis on the specialist's perspective of the coopetitive alliance garnered from semi-structured interviews with 21 valuation specialists employed at large national and global audit firms. We find that the single most influential factor influencing tensions in the auditorspecialist alliance surrounds issues of economic independence and stressors. Specialists perceive that auditors are unwilling to compensate them for their services and limit fee sharing by failing to engage specialists when warranted, restricting the scope of the specialist's work without considering their expert advice, and delaying the engagement of the specialist until the end of the audit (i.e., the last minute). These last-minute requests frustrate specialists because they create undue deadline pressures and can interfere with their ability to service their more profitable projects with non-audit clients. However, when audit firms impose a mandatory policy requiring that auditors consult with specialists for all engagements that meet established risk thresholds, it reduces the likelihood of tensions around last-minute requests for specialist support. Audit firms that have a mandatory consult policy are best positioned to manage what appears to be the greatest threat to audit quality - perceived attempts by auditors to independently evaluate highly complex financial instruments even though they lack the expertise to do so. Specialists report that auditor hubris and underappreciation for the complexity of valuation has led to instances where auditors attempt valuation model building based on googling or recycling prior year models prepared by specialists without consideration of how the inputs can change over time. These perceptions could engender specialist distrust in auditors, make specialists feel that auditors lack respect for their professional judgment, and ultimately escalate tensions in the coopetitive alliance.

Further, when specialists perceive that auditors do not respect or value their expertise and contribution to the audit, they were less likely to take steps to reduce audit risk. Our interviews indicate that in addition to the strategic benefits audit firms reap from having employed specialists, 
the salience of their identity with the firm prompts them to have a higher commitment to safeguarding firm reputation and the quality audit support. Additionally, despite the tensions in the coopetitive alliance, specialists seemed largely willing to provide training and education to auditors to improve the quality of FVMs audits.

Our analysis of the coopetitive framework contributes to the literature and informs practice and regulators. Regulators can glean insights into how issues that diminish or escalate tensions in the auditor-specialist coopetitive alliance could influence the quality of reported FVMs. Further, identifying factors that could reduce the decision-usefulness of audited financial statements and heighten the information risk inherent in FVMs is relevant to all market participants. Audit firms can consider how our findings inform their organizational structure, strategic management, and training of professionals in the auditor-specialist alliance to enhance audit outcomes. Research finds that actively managing rather than suppressing task conflict and tensions in a coopetitive alliance can induce high team performance, facilitate information sharing, and stimulate innovation (Janis 1982; Jehn 1995, 1997; Amason, 1996; Weingart and Jehn 2000; Luo et al. 2006; Olson, Parayitam, and Bao 2007; Locke 2009). Thus, audit firms can design processes that constructively harness and channel the tensions in the auditor-specialist alliance to create outcomes that improve audits of fair value. Further, prior research finds that members who have both audit and valuation traits and skills can serve as "connectors” that enhance team coordination (e.g., Autrey, Bauer, Jackson, and Klevsky 2019). Audit firms can also consider how the organization of specialists within the firm can improve the auditor-specialist alliance to improve audit quality.

It is important to acknowledge the limitations of and design choices in this study. We use an intentionally descriptive approach to evaluate tensions in the auditor-specialist alliance (Malsch and Salterio 2016). We are purposeful in not adopting a prescriptive approach to suggest how these 
factors could or should result in optimal coopetition and collaboration (e.g., Bills et al. 2020). Also, while we describe the specialists' perspectives of how tensions in the coopetitive alliance could influence audit quality, our research does not seek to link the five factors to specific audit outcomes.

Our research complements recent studies examining auditors' use of, interactions with, and reliance on specialists in the audit of complex estimates (e.g., Griffith et al. 2015a; Griffith et al. 2015b; Joe et al. 2017; Brown-Liburd et al. 2019; Griffith 2020) and collaborations with specialists more generally (e.g., Jenkins et al. 2017; Bauer and Estep 2019). This study, however, is not exhaustive. Future research can examine other complexities in the auditor-specialist alliance as well as the interrelation across the five factors in our coopetitive framework. 


\section{References}

Abbott, A. D. 1988. The System of Professions. Chicago, IL: University of Chicago Press.

Aiken, M., and Hage, J. 1968. Organizational interdependence and intra-organizational structure. American Sociological Review 33 (6): 912-930.

Amason, A. 1996. Distinguishing effects of functional and dysfunctional conflict on strategic decision making: Resolving a paradox for top management teams. Academy of Management Journal 39 (1): 123-148.

Ancona, D.G. and D. F. Caldwell. 1992. Demography and design: Predictors of new product team performance. Organization Science 3 (3): 321-341.

Arranz, N., and J. C. F. de Arroyabe. 2008. Joint R\&D projects as complex systems: A framework of analysis. IEEE Transactions on Engineering Management 55 (4): 552-565.

Autrey, R.L., Bauer, T.D., Jackson, K.E. and Klevsky, E., 2019. Deploying “connectors”: A control to manage employee turnover intentions? Accounting, Organizations and Society 79: 101059.

Ayers, D., Dahlstrom, R., and Skinner, S. J. 1997. An exploratory investigation of organizational antecedents to new product success. Journal of Marketing Research 34 (1), 107-116.

Bamber, E. M., D. Snowball, and R. M. Tubbs. 1989. Audit structure and its relation to role conflict and role ambiguity: An empirical investigation. The Accounting Review 64 (2): 285-299.

Barr-Pulliam, D., J. R. Joe, S. A. Mason, and K. Sanderson. 2019. Unlocking the Black Box of Fair Value Measurement for Financial Instruments: The Role and Perspectives of Accounting Firm-Employed Specialists. Whitepaper for the IAASB and ICAS Foundation. Available at: https://www.icas.com/_data/assets/pdf_file/0020/531272/Fair-Value-Barr-PulliamFinal-Report-2020.pdf.

Barr-Pulliam, D., J.-S. Lee, M. Minutti-Meza, and A. B. Zimmerman. 2020. Determinants and Consequences of Auditors' Use of Specialists: Implications for Audit Quality. Working paper, University of Louisville, Public Company Accounting Oversight Board, University of Miami, and Florida State University.

Barr-Pulliam, D., S. A. Mason, and K. Sanderson. 2020. Should I Stay or Should I Go?: The Joint Effects of Valuation Specialists' Knowledge Domain And Employer Type on Perceptions of Organizational-Professional Conflict. Working paper, University of Louisville, DePaul University, Bentley University. 
Barreto, M., and N. Ellemers. 2002. The impact of respect versus neglect of self-identities on identification and group loyalty. Personality and Social Psychology Bulletin 28 (5): 629639.

Bauer, T. D., and C. Estep. 2019. One team or two? Investigating relationship quality between auditors and IT specialists: Implications for audit team identity and the audit process. Contemporary Accounting Research 36 (4): 2142-2177.

Beasley, M., J. Carcello, D. Hermanson, and T. Neal. 2009. The audit committee oversight process. Contemporary Accounting Research 26 (1): 65-122.

Bengtsson, M., and S. Kock. 2000. "Coopetition” in business Networks - to cooperate and compete simultaneously. Industrial Marketing Management 29 (5): 411-426.

Bettenhausen. K. and K. Murnighan. 1985. The Emergence of Norms in Competitive DecisionMaking Groups. Administrative Science Quarterly 30: 350-372.

Bhatt, G. D. 2001. Knowledge management in organizations: examining the interaction between technologies, techniques, and people. Journal of Knowledge Management 5 (1): 68-75.

Bills, K. L., C. Hayne, and S. E. Stein. 2020. Collaborating with Competitors: How Do Small Firm Accounting Associations and Networks Successfully Manage Coopetitive Tensions? Available at: https://papers.ssrn.com/sol3/papers.cfm?abstract_id=3266544.

Boritz, J. E., N. Kochetova, L. A. Robinson, and C. Wong. 2020. Auditors' and specialists' views about the use of specialists during an audit. Behavioral Research in Accounting, Forthcoming.

Bouncken, R. B., J. Gast, S. Kraus, and M. Bogers. 2015. Coopetition: A systematic review, synthesis, and future research directions. Review of Managerial Science 9: 577-601.

Bratten, B., L. M. Gaynor, L. McDaniel, N. R. Montague, and G. E. Sierra. 2013. The audit of fair values and other estimates: The effects of underlying environmental, task, and auditor-specific factors. Auditing: A Journal of Practice \& Theory 32 (Supplement): 744.

Brown-Liburd, H., Mason, S., and S. Shelton, S. 2019. The Effect of Reliance on Third-Party Specialists Under Varying Levels of Internal Control Effectiveness on the Audit of Fair Value Measurements. Working paper, Rutgers, the State University of New Jersey.

Cannon, N. H., and J. C. Bedard. 2016. Auditing challenging fair value measurements: Evidence from the field. The Accounting Review 92 (4): 81-114.

Chakravarthy, B. S., Zaheer, A., and Zaheer, S. 1999. Knowledge sharing in organizations: A field study. Strategic Management Research Center, University of Minnesota. 
Chicago Tribune. 2002. The fall of Andersen. Chicago Illinois. Last downloaded July 23, 2020 at: https://www.chicagotribune.com/news/chi-0209010315sep01-story.html

Choudhary, P. 2011. Evidence on differences between recognition and disclosure: A comparison of inputs to estimate fair values of employee stock options. Journal of Accounting and Economics 51 (1-2): 77-94.

Christensen, B. E., Glover, S. M., and Wood, D. A. 2012. Extreme estimation uncertainty in fair value estimates: Implications for audit assurance. Auditing: A Journal of Practice \& Theory 31 (1), 127-146.

Cicchetti, D. 1994. Guidelines, criteria, and rules of thumb for evaluating normed and standardized assessment instrument in psychology. Psychological Assessment 6 (4): 284290.

Cohen, J. 1960. A coefficient of agreement for nominal scales. Educational and Psychosocial Measurement 20 (1): 37-46.

Cohen, J., G. Krishnamoorthy, and A. Wright. 2002. Corporate governance and the audit process. Contemporary Accounting Research 19 (4): 573-594.

Cohen, J., G. Krishnamoorthy, and A. Wright. 2010. Corporate governance in the post-SarbanesOxley era: Auditors’ experiences. Contemporary Accounting Research 27 (3): 751-786.

Cohen, J., G. Krishnamoorthy, and A. Wright. 2017. Enterprise risk management and the financial reporting process: The experiences of audit committee members, CFOs, and external auditors. Contemporary Accounting Research 34 (2): 1178-1209.

Cohen, J. R., J.R. Joe, J. C. Thibodeau, and G. Trompeter. 2020. Audit Partners’ Judgments and Challenges in the Audit of Internal Control over Financial Reporting. Working paper. Available at: https://papers.ssrn.com/sol3/papers.cfm?abstract_id=3551763.

Covaleski, M., M. W. Dirsmith, J. B. Heian, and S. Samuel. 1998. The calculated and the avowed: Techniques of discipline and struggles over identity in Big Six public accounting firms. Administrative Science Quarterly 43: 293-327.

Czakon, W., and K. Czernek. 2016. The role of trust-building mechanisms in entering into network coopetition: The case of tourism networks in Poland. Industrial Marketing Management 57: 64-74.

Dahl, J. 2014. Conceptualizing coopetition as a process: An outline of change in cooperative and competitive interactions. Industrial Marketing Management 43 (2): 272-279

Davenport, T. H., and L. Prusak. 1998. Working Knowledge: How Organizations Manage What They Know. Boston, MA: Harvard Business School Press. 
Deutsch, M. 1949. A theory of cooperation and competition. Human Relations, 2 (2): 129-152.

DiMaggio, P. J., and W. W. Powell. 1983. The iron cage revisited: Institutional isomorphism and collective rationality in organizational fields. American Sociological Review 48 (2): 14760.

Dodgson, M. 1993. Learning, trust, technological collaboration. Human Relations 46 (1): 77-95.

Donelson, D., M. Ege, A. Imdieke, and E. Maksymov. 2020. The revival of large consulting practices at the Big 4 and audit quality. Accounting, Organizations, and Society (Forthcoming).

Downey, D. H., and J. C. Bedard. 2018. Coordination and communication challenges in global group audits. Auditing: A Journal of Practice \& Theory 38 (1): 123-147.

Downey, D., and K. Westermann. 2019. Challenging Global Group Audits: The Perspective of US Group Audit Leads. Available at: https://papers.ssrn.com/sol3/papers.cfm?abstract_id=3493748.

Earley, C. E., V. Brown, and K. Sanderson. 2020. An Exploratory Analysis of Auditors' Perceptions of the Firms' Tone at the Top. Working paper. Available at: https://papers.ssrn.com/sol3/papers.cfm?abstract_id=3608450.

Farmer, T. A., L. E. Rittenberg, and G. M. Trompeter. 1987. An investigation of the impact of economic and organizational-factors on auditor independence. Auditing: A Journal of Practice \& Theory 7 (1): 1-14.

Feichter, C., I. Grabner, and F. Moers. 2018. Target setting in multi-divisional firms: State of the art and avenues for future research. Journal of Management Accounting Research 30 (3): 29-54.

Fernandez, A.S., P. Chiambaretto, F. Le Roy, and W. Czakon, eds. 2018. Routledge Companion to Coopetition Strategies. Abingdon, U.K.: Routledge.

Fernandez, A.S., F. Le Roy, and. R. Gnyawali. 2014. Sources and management of tension in coopetition case evidence from telecommunications satellites manufacturing in Europe. Industrial Marketing Management 43 (2): 222-235.

Financial Accounting Standards Board (FASB). 2011. Fair Value Measurements \& Disclosures. Statement of Financial Accounting Standards (SFAS) ASC 820. Norwalk, CT: FASB.

Garrett, T. C., Buisson, D. H., and Yap, C. M. 2006. National culture and R\&D and marketing integration mechanisms in new product development: A cross-cultural study between Singapore and New Zealand. Industrial Marketing Management 35 (3), 293-307. 
Gendron, Y., J. Bédard, and M. Gosselin. 2004. Getting inside the blackbox: A field study of practices in "effective" audit committees. Auditing: A Journal of Practice and Theory 23 (1): 153-171.

Ghoshal, S., H. Korine, and G. Szulanski. 1994. Interunit communication in multinational corporations. Management Science 40 (1): 96-110.

Gilmour, D. 2003. How to fix knowledge management. Harvard Business Review 81: 16-17.

Glover, S. M., M. H. Taylor, and Y. J. Wu. 2017. Current practices and challenges in auditing fair value measurements and complex estimates: Implications for auditing standards and the academy. Auditing: A Journal of Practice \& Theory 36 (1): 63-84.

Glover, S. M., M. H. Taylor, and Y. J. Wu. 2019. Mind the gap: Why do experts have differences of opinion regarding the sufficiency of audit evidence supporting complex fair value measurements? Contemporary Accounting Research 36 (3): 1417-1460.

Gnyawali, D.R., R. Madhavan, J. He, and M. Bengtsson. 2016. The competition-cooperation paradox in inter-firm relationships: A conceptual framework. Industrial Marketing Management 53: 7-18.

Gnyawali, D.R., and B.-J. Park. 2009. Co-opetition and technological innovation in small and medium-sized enterprises: A multilevel conceptual model. Journal of Small Business Management 47 (3): 308-330.

. 2011. Co-opetition between giants: Collaboration with competitors for technological innovation. Research Policy 40(5): 650-663.

Golden-Biddle, K., and K. Locke. 2007. Composing Qualitative Research. 2nd edition. Thousand Oaks, CA: Sage Publications.

Gottschalg, O., and M. Zollo. 2007. Interest alignment and competitive advantage. Academy of Management Review 32 (2): 418-437.

Grant, R. M. 1996. Toward a knowledge-based theory of the firm. Strategic Management Journal 17 (S2), 109-122.

Griffin, A., and Hauser, J. R. 1996. Integrating R\&D and marketing: A review and analysis of the literature. Journal of Product Innovation Management: An International Publication of the Product Development \& Management Association 13 (3), 191-215.

Griffith, E. E. 2018. When do auditors use specialists' work to improve problem representations of and judgments about complex estimates? The Accounting Review 93 (4): 177-202.

Griffith, E. E. 2020. Auditors, specialists, and professional jurisdiction in audits of fair values. Contemporary Accounting Research 37 (1): 245-276. 
Griffith, E. E., J. S. Hammersley, and K. Kadous. 2015a. Audits of complex estimates as verification of management numbers: How institutional pressures shape practice. Contemporary Accounting Research 32 (3): 833-863.

Griffith, E. E., J. S. Hammersley, K. Kadous, and D. Young. 2015b. Auditor mindsets and audits of complex estimates. Journal of Accounting Research 53 (1): 49-77.

Gulati, R., N. Nohria, and A. Zaheer. 2000. Strategic networks. Strategic Management Journal 21 (3): 203-215.

Gulati, R., and H. Singh. 1998. The architecture of cooperation: Managing coordination costs and appropriation concerns in strategic alliances. Administrative Science Quarterly 43 (4): 781-814.

Gulati, R., F. Wohlgezogen, and P. Zhelyazkov. 2012. The two facets of collaboration: Cooperation and coordination in strategic alliances. The Academy of Management Annals 6 (1): 531-583.

Hackenbrack, K., and M. W. Nelson. 1996. Auditors' incentives and their application of financial accounting standards. Accounting Review 71 (1): 43-59.

Han, J., K. Jamal, and H. Tan. 2011. Auditors' overconfidence in predicting the technical knowledge of superiors and subordinates. Auditing: A Journal of Practice \& Theory 30 (1): 101-19.

Hansen, M. T. 1999. The search-transfer problem: The role of weak ties in sharing knowledge across organization subunits. Administrative Science Quarterly 44 (1), 82-111.

Hilton, A. S., and P. C. O’Brien. 2009. Inco Ltd.: Market value, fair value, and management discretion. Journal of Accounting Research 47 (1), 179-211.

Hirst, D., and L. Koonce. 1996. Audit analytical procedures: A field investigation. Contemporary Accounting Research 13 (2): 457-486.

Hong, J. F. L., and S. Vai. 2008. Knowledge-sharing in cross-functional virtual teams. Journal of General Management 34 (2): 21-37.

Huber, G. P., and D. J. Power. 1985. Retrospective reports of strategic-level managers: Guidelines for increasing their accuracy. Strategic Management Journal 6 (2): 171-180.

Hux, C.T., 2017. Use of specialists on audit engagements: A research synthesis and directions for future research. Journal of Accounting Literature, 39: 23-51.

Ichijo, K., G. von Krogh, and I. Nonaka. 1998. Knowledge enablers. In Knowing in Firms: Understanding, Managing and Measuring Knowledge, edited by G. von Krogh, J. Roos, and D. Kleine, 173-203. London, U.K.: Sage. 
IFRS Foundation. 2011. Fair Value Measurement. International Financial Reporting Standard (IFRS) 13. London, U.K.: IFRS Foundation.

Iyer, V. M., E. M. Bamber, and R. M. Barefield. 1997. Identification of accounting firm alumni with their former firm: Antecedents and outcomes. Accounting, Organizations and Society 22 (3-4): 315-336.

Janis, I. L. 1982. Victims of Groupthink. 2nd edition. Boston, MA: Houghton - Mifflin.

Jansen, J. J., Van Den Bosch, F. A., and Volberda, H. W. 2005. Managing potential and realized absorptive capacity: how do organizational antecedents matter?. Academy of Management Journal 48 (6), 999-1015.

Jehn, K. 1995. A multimethod examination of the benefits and detriments of intragroup conflict. Administrative Science Quarterly. 40, 256-282.

Jehn, K. 1997. A qualitative analysis of conflict types and dimensions in organizational groups. Administrative Science Quarterly. 42, 530-557.

Jenkins, J. G., Negangard, E. M., and Oler, M. J. 2018. Getting comfortable on audits: Understanding firms' usage of forensic specialists. Contemporary Accounting Research 35 (4), 1766-1797.

Joe, J. R., D. Janvrin, D. Barr-Pulliam, S. Mason, M. K. Pitman, Z. Rezaee, K. Sanderson, and Y. J. Wu. 2015. Comments of the Auditing Standards Committee of the Auditing Section of the American Accounting Association on PCAOB Staff Consultation Paper No. 2015-01, The auditors' use of the work of specialists. Current Issues in Auditing 9 (2): C18-C37.

Joe, J. R., S. D. Vandervelde, and Y. J. Wu. 2017. Use of high quantification evidence in fair value audits: Do auditors stay in their comfort zone? The Accounting Review 92 (5): 89-116.

Johnson, D. W., and R. T. Johnson. 2005. New developments in social interdependence theory. Genetic, Social, and General Psychology Monographs 131 (4): 285-358.

Johnson, L. M., M. B. Keune, and J. Winchel. 2019. US auditors' perceptions of the PCAOB inspection process: A behavioral examination. Contemporary Accounting Research 36 (3): 1540-1574.

Johnson, M. D., J. R. Hollenbeck, S. E. Humphrey, D. R. Ilgen, D. Jundt, and C. J. Meyer. 2006. Cutthroat cooperation: Asymmetrical adaptation to changes in team reward structures. Academy of Management Journal 49 (1): 103-119.

Jonsen, K., J. Fendt, and S. Point. 2018. Convincing qualitative research: What constitutes persuasive writing? Organizational Research Methods 21 (1): 30-67. 
Kadous, K., S. J. Kennedy, and M. E. Peecher. 2003. The effect of quality assessment and directional goal commitment on auditors' acceptance of client-preferred accounting methods. The Accounting Review 78 (3): 759-778.

Kang, J. K., C. Lennox, and V. Pandey. 2019. Transferring Knowledge or Proprietary Information? An Examination of Audit Clients Who Share the Same Audit Partner. Working paper, University of Southern California.

Kennedy, J., and M. E. Peecher. 1997. Judging auditors’ technical knowledge. Journal of Accounting Research 35 (2): 279-293.

Khanna, T., R. Gulati, and N. Nohria. 1998. The dynamics of learning alliances: Competition, cooperation, and relative scope. Strategic Management Journal 19 (3): 193-210.

Kiesler. S. B. 1978. Interpersonal Processes in Groups and Organizations. Arlington Heights. IL: AHM Publishing.

Kogut, B., and Zander, U. 1996. What firms do? Coordination, identity, and learning. Organization Science 7 (5), 502-518.

Lado, A. A., N. Boyd, and S. C. Hanlon. 1997. Competition, cooperation, and the search for economic rents: A syncretic model. Academy of Management Review 22 (1): 110-141.

Layder, D. 1998. Sociological Practice: Linking Theory and Social Research. London U.K.: Sage Publications.

Le Roy, F., and A.-S. Fernandez. 2015. Managing coopetitive tensions at the working-group level: The rise of the coopetitive project team. British Journal of Management 26 (4), 671688.

Le Roy F., A.-S. Fernandez, and P. Chiambaretto P. 2018. From strategizing coopetition to managing coopetition. In The Routledge Companion to Coopetition Strategies, edited by A.-S., P. Fernandez Chiambaretto, F. Le Roy, and W. Czakon. Abingdon, U.K.: Routledge.

Li, J. and D.C. Hambrick. 2005. Factional groups: A new vantage on demographic faultlines, conflict, and disintegration in work teams. Academy of Management Journal 48 (5): 794813.

Lillis, A. M. 1999. A framework for the analysis of interview data from multiple field research sites. Accounting \& Finance 39 (1): 79-105.

Lincoln, Y. S., and E. G. Guba. 1985. Naturalistic inquiry (Vol. 75). Beverly Hills, CA: Sage Publications.

Locke, E. A. 2009. Handbook of Principles of Organizational Behavior. 2nd edition. West Sussex, NJ: John Wiley \& Sons. 
Loebecke, C., Van Fenema, P. C., and Powell, P. 1999. Co-opetition and knowledge transfer. ACM SIGMIS Database: The DATABASE for Advances in Information Systems 30 (2): 14-25.

Lorange, P. 1996. Interactive strategies-Alliances and partnerships. Long Range Planning 29 (4): 581-584.

Love, J. H., and S. Roper, S. 2009. Organizing innovation: Complementarities between crossfunctional teams. Technovation 29 (3): 192-203.

Lovelace, K., D. L. Shapiro, and L. R. Weingart. 2001. Maximizing crossfunctional new product teams' innovativeness and constraint adherence: A conflict communications perspective. Academy of Management Journal 44 (4): 779-783.

Luippold, B. L., and T. E. Kida. 2012. The impact of initial information ambiguity on the accuracy of analytical review judgments. Auditing: A Journal of Practice \& Theory 31 (2): 113-129.

Luo, X., R. J. Slotegraaf, and X. Pan. 2006. Cross-functional “coopetition”: The simultaneous role of cooperation and competition within firms. Journal of Marketing 70 (2): 67-80.

Malsch, B., and S. E. Salterio. 2016. "Doing good field research”: Assessing the quality of audit field research. Auditing: A Journal of Practice \& Theory 35 (1): 1-22.

Martin, R. D., J. S. Rich, and T. J. Wilks. 2006. Auditing fair value measurements: A synthesis of relevant research. Accounting Horizons 20 (3): 287-303.

Martinez, J. I., and Jarillo, J. C. 1989. The evolution of research on coordination mechanisms in multinational corporations. Journal of International Business Studies 20 (3), 489-514.

Menon, A., S. G. Bharadwaj, P. T. Adidam, and S. W. Edison. 1999. Antecedents and consequences of marketing strategy making: A model and a test. Journal of Marketing 63 (2): $18-40$.

Menon, A., B. J. Jaworski, and A. K. Kohli. 1997. Product quality: Impact of interdepartmental interactions. Journal of the Academy of Marketing Science 25 (3), 187-200.

Menon, A., and P. R. Varadarajan. 1992. A model of marketing knowledge use within firms. Journal of Marketing 56 (4): 53-71.

Miles, M. B., and A. M. Huberman. 1994. Qualitative Data Analysis: An Expanded Sourcebook. Beverly Hills, CA: Sage.

Mintzberg, H. 1979. The Structuring of Organizations. Englewood Cliffs, NJ: Prentice Hall.

Morse, J. M. 1995. The significance of saturation. Qualitative Health Research 5:147-149. 
Morse, J. M. 2000. Determining sample size. Qualitative Health Research 10 (1): 3-5.

Nalebuff, B., and A. Brandenburger. 1996. Co-opetition. New York, NY: Currency Doubleday.

Olson, B. J., Parayitam, S., and Bao, Y. 2007. Strategic decision making: the effects of cognitive diversity, conflict, and trust on decision outcomes. Journal of Management, (33), 196-222.

Olson, E. M., Walker Jr, O. C., and Ruekert, R. W. 1995. Organizing for effective new product development: The moderating role of product innovativeness. Journal of Marketing 59 (1), 48-62.

Padula, G., and B. Dagnino. 2007. Untangling the rise of coopetition: The intrusion of competition in a cooperative game structure. International Studies of Management \& Organization 37 (2): 32-52.

Patton, M. 2015. Qualitative Research \& Evaluation Methods. Beverly Hills, CA: Sage Publications Inc.

Peng, T. J. A., S. Pike, J. C. H. Yang, and G. Roos. 2012. Is cooperation with competitors a good idea? An example in practice. British Journal of Management 23 (4): 532-560.

Pertusa-Ortega, E. M., Zaragoza-Sáez, P., and Claver-Cortés, E. 2010. Can formalization, complexity, and centralization influence knowledge performance?. Journal of Business Research 63 (3), 310-320.

Porter, M. E. 1980. Competitive Strategy: Techniques for Analyzing Industries and Competition. New York, NY: The Free Press.

Power, M. K., and Y. Gendron. 2015. Qualitative research in auditing: A methodological roadmap. Auditing: A Journal of Practice \& Theory 34 (2): 147-165.

Pratt, M.G., 2009. From the editors: For the lack of a boilerplate: Tips on writing up (and reviewing) qualitative research. The Academy of Management Journal 52 (5): 856-862.

Pratt, J., and J. Jiambalvo. 1981. Relationships between leader behaviors and audit team performance. Accounting, Organizations and Society 6 (2): 133-142.

Public Company Accounting Oversight Board (PCAOB). 2018. Amendments to Auditing Standards for Auditor's Use of the Work of Specialists. PCAOB Release No. 2018-006 December 20, 2018. PCAOB Rulemaking Docket Matter No. 044. Washington, D.C.: PCAOB. Available at: https://pcaobus.org/Rulemaking/Docket044/2018-006-specialistsfinal-rule.pdf.

. 2015a. Fact Sheet: Staff Consultation Paper on the Auditor's Use of the Work of Specialists. May 28. Washington, D.C.: PCAOB, 2015a. Available at: http://pcaobus.org/News/Releases/Pages/Specialist_Fact_Sheet.aspx. 
Public Company Accounting Oversight Board (PCAOB). 2015b. Staff Consultation Paper No. 2015-01, the Auditors' Use of the Work of Specialists. Washington, D.C.: PCAOB, 2015b. Available at: http://pcaobus.org/Standards/Documents/SCP-2015

01_The_Auditor's_Use_of_the_Work_of_Specialists.pdf.

. 2017. Proposed Auditing Standard - Auditing Accounting Estimates, Including Fair Value Measurements and Proposed Amendments To PCAOB Auditing Standards: PCAOB Release No. 2017-002 June 1, 2017. PCAOB Rulemaking Docket Matter No. 043. Washington, $\quad$ D.C.: $\quad$ PCAOB, 2017b. Available at: https://pcaobus.org/Rulemaking/Docket043/2017-002-auditing-accounting-estimatesproposed-rule.pdf.

2017a. Proposed Amendments to Auditing Standards for Auditor's Use of the Work of Specialists. PCAOB Release No. 2017-003 June 1, 2017. PCAOB Rulemaking Docket Matter No. 044. Washington, D.C.: PCAOB, 2017a. Available at:

https://pcaobus.org/Rulemaking/Docket044/2017-003-specialists-proposed-rule.pdf.

2017c. The Auditor's Report on an Audit of Financial Statements When the Auditor Expresses an Unqualified Opinion. PCAOB Release No. 2017-001 June 1, 2017. PCAOB Rulemaking Docket Matter No. 034. Washington, D.C.: PCAOB, 2017c. Available at: https://pcaobus.org/Rulemaking/Docket034/2017-001-auditors-report-final-rule.pdf.

Quintana-Garcia, C., and C. A. Benavides-Velasco. 2004. Cooperation, competition, and innovative capability: A panel data of European dedicated biotechnology firms. Technovation 24 (12): 927-938.

Rapley, T. 2011. Some pragmatics of data analysis. In Doing Qualitative Research, edited by D. Silverman, 273-290. London, U. K.: Sage Publications.

Raza-Ullah, T., M. Bengtsson, and S. Kock. 2014. The coopetition paradox and tension in coopetition at multiple levels. Industrial Marketing Management 43 (2): 189-198.

Ritala, P. 2012. Coopetition strategy-when is it successful? Empirical evidence on innovation and market performance. British Journal of Management 23 (3): 307-324.

Ritala, P., and P. Hurmelinna-Laukkanen. 2009. What's in it for me? Creating and appropriating value in innovation-related coopetition. Technovation 29 (12), 819-828.

Ritala, P., and A. Tidström. 2014. Untangling the value-creation and value-appropriation elements of coopetition strategy: A longitudinal analysis on the firm and relational levels. Scandinavian Journal of Management 30 (4): 498-515.

Sandelowski, M. 2008. Theoretical saturation. In The SAGE Encyclopedia of Qualitative Research Methods, edited by L. M. Given. Thousand Oaks, CA: Sage. 
Scott, W. R. 2014. Institutions and Organizations: Ideas, Interests, and Identities. 4th edition. London, U.K.: Sage.

Shih, M., H. Tsai, C. Wu, and C. Lu. 2006. A holistic knowledge sharing framework in high-tech firms: Game and co-opetition perspectives. International Journal of Technology Management 36 (4): 354-367.

Silverman, D. 2010. Introducing qualitative research. In Doing Qualitative Research, edited by D. Silverman, 3-12. London, U.K.: Sage Publications.

Sullivan, S. E., and R. S. Bhagat. 1992. Organizational stress, job satisfaction and job performance: Where do we go from here? Journal of Management 18: 353-374.

Tjosvold, D., D. W. Johnson, R. T. Johnson, and H. Sun. 2003. Can interpersonal competition be constructive within organizations? The Journal of Psychology 137 (1): 63-84.

Trompeter, G., and A. Wright. 2010. The world has changed: Have analytical procedure practices? Contemporary Accounting Research 27 (3): 669-700.

Tsai, W. 2002. Social structure of "coopetition" within a multiunit organization: Coordination, competition, and intraorganizational knowledge sharing. Organization Science 13 (2): 179-190.

Tsai, K. H., and Hsu, T. T. 2014. Cross-Functional collaboration, competitive intensity, knowledge integration mechanisms, and new product performance: A mediated moderation model. Industrial Marketing Management 43 (2), 293-303.

Van Der Bij, H., M. X. Song, and M. Weggeman. 2003. An empirical investigation into the antecedents of knowledge dissemination at the strategic business unit level. Journal of Product Innovation Management 20 (2): 163-179.

Walley, K. 2007. Coopetition: An introduction to the subject and an agenda for research. International Studies of Management \& Organization 37 (2): 11-31.

Wasko, M. M., and S. Faraj. 2000. "It is what one does": Why people participate and help others in electronic communities of practice. The Journal of Strategic Information Systems 9 (23): $155-173$.

Weingart, L. R., and K. A. Jehn. 2000. Manage intra-team conflict through collaboration. The Blackwell Handbook of Principles of Organization Behavior, 226-238. Oxford, U.K.: Blackwell Publishers.

Westermann, K., J. Bedard, and C. Earley. 2015. Learning the "craft" of auditing: A dynamic view of auditors' on-the-job learning. Contemporary Accounting Research 32 (3): 864896. 
Westermann, K.D., J. Cohen, and G. Trompeter. 2019. PCAOB inspections: Public accounting firms on "trial.” Contemporary Accounting Research 36 (2): 694-731.

Wiener, Y. 1982. Commitment in organizations: A normative view. Academy of Management Review, 7(3), 418-428.

Willer, R. 2009. Groups reward individual sacrifice: The status solution to the collective action problem. American Sociological Review 74: 23-43.

Yin, R. K. 2014. Case study research: Design and methods (applied social research methods). Thousand Oaks, CA: Sage publications. 
FIGURE 1

The Coopetitive Alliance Tradeoff

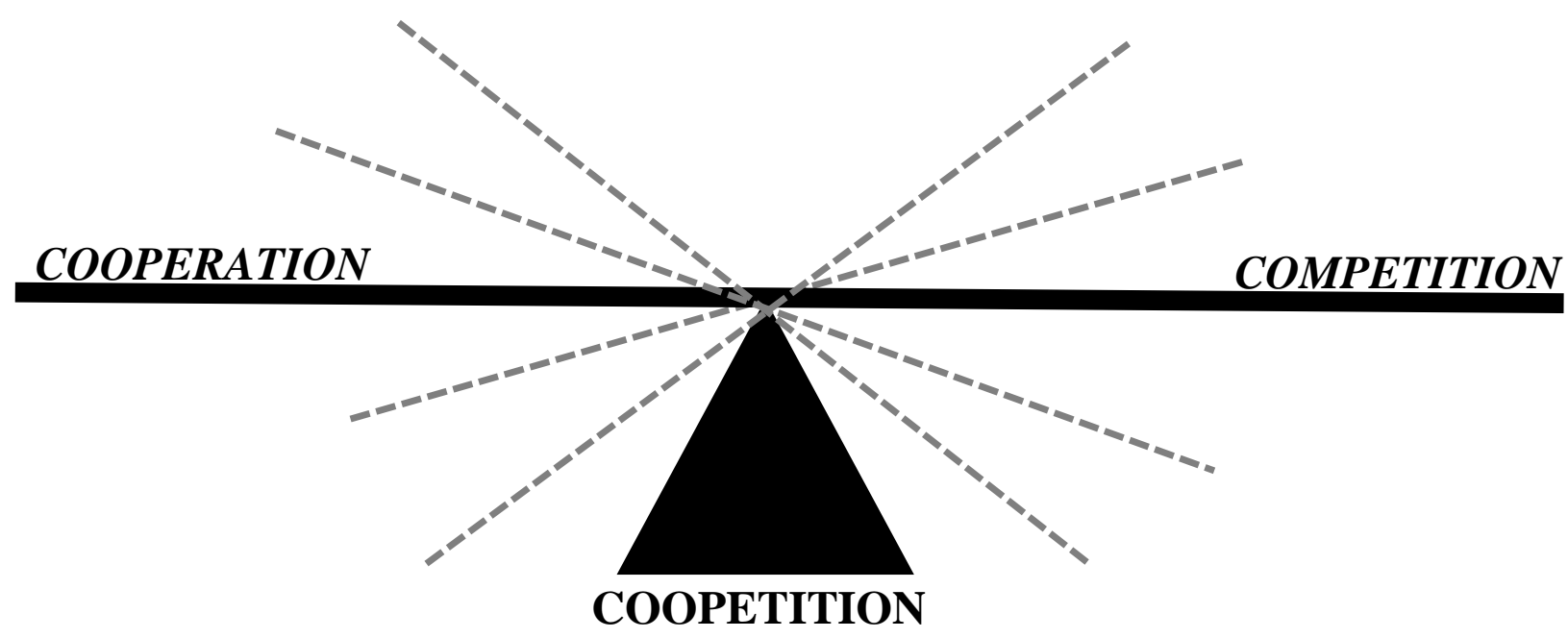

Note: This figure illustrates the possible ways auditors and specialists can balance competition and cooperation in their coopetitive alliance. Importantly, our coopetition framework in the auditor-specialist alliance does not prescribe an optimal combination of competition and cooperation; instead, we consider the factors that can enhance or detract from their alliance. Figure 2 presents the five factors that affect the coopetitive alliance. 
FIGURE 2

Factors Impacting the Auditor-Specialist Coopetitive Alliance

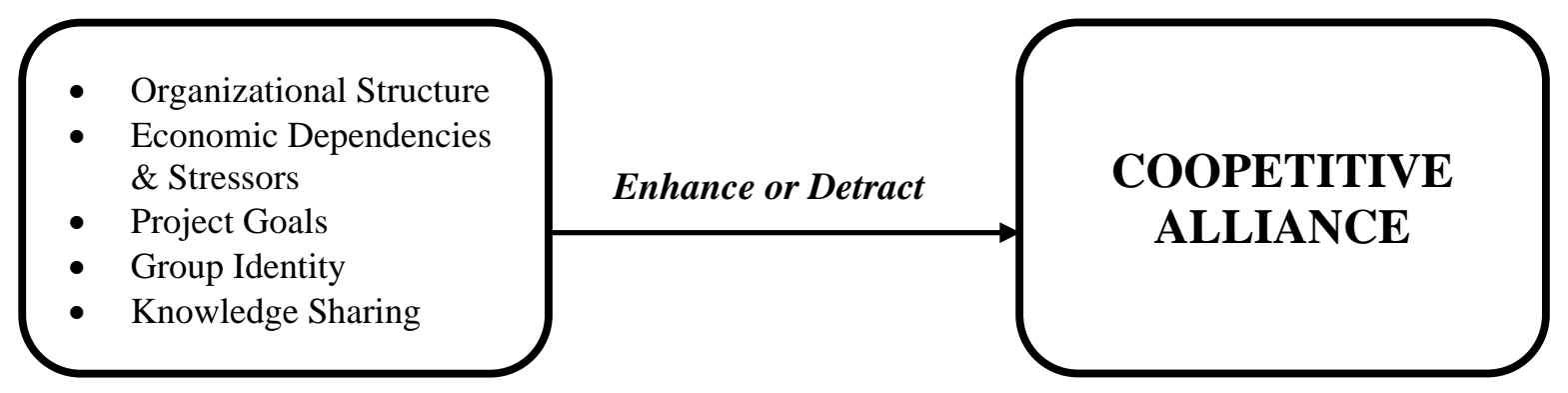

Note: This figure illustrates the five factors in the coopetition framework that influence (enhance or detract from) the coopetitive alliance between auditors and specialists in the audit of fair value.

Definition of Terms

Organizational Structure refers to the policies and structures put in place by the institution to govern the units and interactions in the coopetitive alliance.

Economic Dependencies \& Stressors refer to conflicts related to the allocation of resources between the parties in the coopetitive alliance and extent to which the parties are resource independent of each other.

Project Goals refers to each unit's orientation towards the coopetitive product and whether or not the units' goals are aligned.

Group Identity refers to the extent to which the members of the coopetitive alliance share a collectivist view that embodies the unified goals and strategies of the parent organization versus a salient social and psychological bond with their functional unit.

Knowledge Sharing refers to the willingness of parties in the alliance to share knowledge related to the coopetitive product. 
TABLE 1

Interview Participant Demographics

\section{Panel A: Firm Size and Years' Experience}

\begin{tabular}{|c|c|c|c|c|c|c|}
\hline Participant ID & Firm Size & Location & Professional Title & $\begin{array}{l}\text { Years with } \\
\text { Employer }\end{array}$ & $\begin{array}{c}\text { Years } \\
\text { Professional } \\
\text { Experience } \\
\end{array}$ & $\begin{array}{c}\text { Years } \\
\text { Valuation } \\
\text { Experience } \\
\end{array}$ \\
\hline $\mathrm{P} 1$ & Non-Big4 & US & Managing Director & $<6$ years & $>15$ years & $6-10$ years \\
\hline $\mathrm{P} 2$ & Non-Big4 & US & Director & $6-10$ years & $11-15$ years & 11 - 15 years \\
\hline P3 & Big4 & US & Managing Director & $6-10$ years & $>15$ years & $>15$ years \\
\hline $\mathrm{P} 4$ & Big4 & Asia Pacific - HK & Manager & $<6$ years & $6-10$ years & $6-10$ years \\
\hline P5 & Non-Big4 & Europe - UK & Manager & $<6$ years & $<6$ years & $<6$ years \\
\hline P6 & Non-Big4 & Europe - UK & Manager & $6-10$ years & $11-15$ years & $6-10$ years \\
\hline P7 & Non-Big4 & US & Partner & $<6$ years & $>15$ years & $11-15$ years \\
\hline P8 & Big4 & US & Partner & $11-15$ years & > 15 years & $6-10$ years \\
\hline P9 & Big4 & US & Senior Manager & $11-15$ years & $11-15$ years & $11-15$ years \\
\hline P10 & Triennial & US & Senior Manager & $11-15$ years & $11-15$ years & $6-10$ years \\
\hline P11 & Big4 & Europe - UK & Audit Senior Manager & $6-10$ years & $6-10$ years & $6-10$ years \\
\hline P12 & Big4 & Europe - UK & Audit Senior Manager & $6-10$ years & $6-10$ years & $6-10$ years \\
\hline P13 & Triennial & US & Director & $<6$ years & $11-15$ years & $6-10$ years \\
\hline P14 & Non-Big4 & US & Director & $11-15$ years & $11-15$ years & $11-15$ years \\
\hline P15 & Big4 & US & Managing Director & $6-10$ years & $11-15$ years & $11-15$ years \\
\hline P16 & Non-Big4 & US & Managing Director & $6-10$ years & $6-10$ years & $6-10$ years \\
\hline P17 & Non-Big4 & US & Manager & $<6$ years & $6-10$ years & $6-10$ years \\
\hline P18 & Big4 & Europe - UK & Partner & $>15$ years & > 15 years & $>15$ years \\
\hline P19 & Big4 & Canada & Partner & $>15$ years & $>15$ years & $11-15$ years \\
\hline P20 & Big4 & US & Partner & $>15$ years & $>15$ years & > 15 years \\
\hline $\mathrm{P} 21$ & Triennial & US & Senior Manager & $<6$ years & $>15$ years & $11-15$ years \\
\hline \multicolumn{4}{|c|}{ \% Participants with at least 11 years' experience } & 33.3 & 71.4 & 52.4 \\
\hline
\end{tabular}


TABLE 1 (continued)

Interview Participant Demographics

Panel B: Participant's Self-Reported Prior Experience

\begin{tabular}{|c|c|c|c|c|c|c|}
\hline \multirow[b]{2}{*}{$\begin{array}{c}\text { Participant } \\
\text { ID } \\
\end{array}$} & \multirow[b]{2}{*}{$\begin{array}{l}\text { Prior Audit } \\
\text { Experience }\end{array}$} & \multicolumn{5}{|c|}{ Prior Experience as a Specialist Across Employer Types } \\
\hline & & $\begin{array}{c}\text { Big4 } \\
\text { Accounting Firm } \\
\end{array}$ & $\begin{array}{c}\text { NonBig4 } \\
\text { Accounting Firm } \\
\end{array}$ & $\begin{array}{c}\text { Independent } \\
\text { Valuation Firm } \\
\end{array}$ & $\begin{array}{l}\text { Financial } \\
\text { Institution } \\
\end{array}$ & $\begin{array}{c}\text { In-House } \\
\text { (Private/Public/None) }\end{array}$ \\
\hline $\mathrm{P} 1$ & No & No & Yes & Yes & Yes & Private and Public \\
\hline $\mathrm{P} 2$ & No & Yes & Yes & No & No & None \\
\hline P3 & No & No & No & Yes & No & None \\
\hline $\mathrm{P} 4$ & No & Yes & No & No & Yes & None \\
\hline P5 & Yes & No & Yes & No & No & None \\
\hline P6 & No & No & Yes & No & Yes & None \\
\hline P7 & Yes & Yes & Yes & No & No & None \\
\hline P8 & Yes & Yes & No & No & Yes & None \\
\hline P9 & Yes & No & Yes & No & No & None \\
\hline $\mathrm{P} 10$ & No & No & No & No & No & None \\
\hline $\mathrm{P} 11$ & Yes & Yes & No & No & No & None \\
\hline $\mathrm{P} 12$ & No & No & No & No & No & None \\
\hline $\mathrm{P} 13$ & No & No & Yes & No & No & None \\
\hline $\mathrm{P} 14$ & No & No & Yes & No & No & None \\
\hline P15 & Yes & No & No & No & Yes & None \\
\hline P16 & No & No & Yes & No & No & None \\
\hline $\mathrm{P} 17$ & No & No & Yes & No & Yes & Private \\
\hline P18 & No & Yes & No & No & No & None \\
\hline P19 & No & Yes & No & No & No & None \\
\hline $\mathrm{P} 20$ & No & No & No & No & No & None \\
\hline $\mathrm{P} 21$ & Yes & Yes & No & No & Yes & Private \\
\hline Percentage "Yes" & 33.3 & 38.1 & 47.6 & 9.5 & 33.3 & 14.3 \\
\hline
\end{tabular}


TABLE 1 (continued)

Interview Participant Demographics

Panel C: Credentials and Types of Valuations Prepared or Reviewed

\begin{tabular}{|c|c|c|c|c|c|}
\hline Participant ID & Degree & Certification(s) & Gender & $\begin{array}{l}\text { Num. Level } 3 \text { Financial } \\
\text { Instruments (Review) }\end{array}$ & $\begin{array}{l}\text { Num. Level } 3 \text { Financial } \\
\text { Instruments (Prepare) }\end{array}$ \\
\hline $\mathrm{P} 1$ & Ph. D. & FINRA 79/63 & Male & 100 & 25 \\
\hline $\mathrm{P} 2$ & Master's Degree (Other) & CFA & Female & 50 & 50 \\
\hline P3 & Master's Degree (MBA) & CFA, CPA & Male & 55 & 20 \\
\hline P4 & Ph. D. & -- & Male & 100 & 100 \\
\hline P5 & Master's Degree (Other) & ACA & Male & 3 & 0 \\
\hline P6 & Bachelor's Degree & FIA, CERA & Male & 56 & 14 \\
\hline P7 & Bachelor's Degree & --- & Female & 150 & 300 \\
\hline P8 & Master's Degree (MBA) & ABV, CFA, CPA, FRM & Male & 100 & 40 \\
\hline P9 & Master's Degree (Other) & ACA, CFA, CGMA, CPA & Male & 250 & 400 \\
\hline P10 & Bachelor's Degree & CFA & Male & 15 & 10 \\
\hline P11 & Bachelor's Degree & ACA, CFA, MCSI & Female & 200 & 0 \\
\hline $\mathrm{P} 12$ & Bachelor's Degree & CPA & Male & 100 & 0 \\
\hline $\mathrm{P} 13$ & Master's Degree (MBA) & CFA, CVA & Male & 10 & 20 \\
\hline P14 & Master's Degree (MBA) & CFA, CPA & Male & 50 & 50 \\
\hline $\mathrm{P} 15$ & Master's Degree (Other) & CFA, CPA & Male & 50 & 300 \\
\hline P16 & Ph. D. & CFA & Male & 35 & 17.5 \\
\hline $\mathrm{P} 17$ & Master's Degree (MBA) & CFA & Female & 100 & 100 \\
\hline P18 & Master's Degree (MBA) & ACA & Male & 50 & 500 \\
\hline P19 & Bachelor's Degree & FRM & Male & 75 & 37.5 \\
\hline P20 & Master's Degree (MBA) & CFA & Male & 100 & 500 \\
\hline P21 & Master's Degree (MBA) & ASA & Male & 10 & 50 \\
\hline AVERAGES & $\begin{array}{l}\text { 66.7\% Hold Master's } \\
\text { Degree or Higher }\end{array}$ & $\begin{array}{l}\text { 90.5\% Hold at least } \\
\text { One Certification }\end{array}$ & $\begin{array}{l}81.0 \% \\
\text { Male }\end{array}$ & 79 & 120.7 \\
\hline
\end{tabular}


TABLE 2

\section{Summary of Findings}

\begin{tabular}{|c|c|}
\hline Coopetition Framework Factor & Key Findings \\
\hline $\begin{array}{l}\text { Organizational Structure: } \\
\text { - Coordination through a vertically imposed bureaucratic process } \\
\text { by the parent firm prevents units from exercising discretion and } \\
\text { discourages informal networks. } \\
\text { - Parent imposed organizational structure decreases motivation } \\
\text { for the coopetitive product. } \\
\text { - Centralization creates greater physical distance between the } \\
\text { specialists and auditors, which limits opportunities to build } \\
\text { trust. } \\
\text { - Centralization limits alternative paths to de-escalating tensions. }\end{array}$ & $\begin{array}{l}\text { A decentralized approach contributes to lower quality valuation because } \\
\text { there is lower demand for specialists work and the opportunity to develop } \\
\text { technical expertise is limited. } \\
\text { Lack of a mandatory specialist consultation policy leads auditors to } \\
\text { attempt valuation work outside of their competence and use unsupported } \\
\text { models. } \\
\text { Some firms have employed a unique group of "hybrid-specialists" who } \\
\text { have significant audit and valuation expertise to facilitate collaboration } \\
\text { across the audit and specialist units. }\end{array}$ \\
\hline $\begin{array}{l}\text { Economic Dependencies and Stressors: } \\
\text { - Tensions arise over the economic benefit (fee sharing) each } \\
\text { unit extracts from the alliance. } \\
\text { - Ownership/control of the economic benefits and each unit's } \\
\text { ability to extract economic benefit from the alliance exacerbate } \\
\text { tensions. } \\
\text { - When the parent firm requires the specialist unit to be self- } \\
\text { sufficient, it exacerbates tensions. }\end{array}$ & $\begin{array}{l}\text { Because specialists earn higher fees and capitation rates on external } \\
\text { consulting than on audit support: } \\
\text { - Conflicts arise when auditor actions limit/inhibit their ability to service } \\
\text { non-audit clients. } \\
\text { - Audit work is seen as less desirable. } \\
\text { - Specialists specializing in audit work feel less respected. } \\
\text { - Specialists prioritize non-audit work over audit support services. } \\
\text { There is significant delay in engaging specialists and auditors often wait } \\
\text { until the last minute or when they are "forced" to do so, which creates } \\
\text { deadline pressures on the valuation task. } \\
\text { Specialists resent that auditors are unwilling to pay for their services and } \\
\text { believe that excluding them from scoping decisions can inappropriately } \\
\text { restrict testing of the client's FVM. }\end{array}$ \\
\hline
\end{tabular}


TABLE 2 (continued)

Summary of Findings

\begin{tabular}{|c|c|}
\hline Coopetition Framework Factor & Key Findings \\
\hline Economic Dependencies and Stressors (continued): & $\begin{array}{l}\text { Auditor delay in retaining specialist and restriction in budgeted time } \\
\text { allocated for specialists leads to reduced effort in testing the client's FVM. } \\
\text { Specialists view audit support services as an opportunity to enhance skills } \\
\text { and, ultimately, their non-audit client fees. } \\
\text { Hybrid specialists face unique stress, they are more committed to providing } \\
\text { high quality audit support service but feel pressured into performing that } \\
\text { work during after-hours. }\end{array}$ \\
\hline $\begin{array}{l}\text { Project Goals: } \\
\text { - Shared understanding and common goals enhance the } \\
\text { coopetitive relationship. } \\
\text { - Divergent goals limit coordination and detract from the } \\
\text { coopetitive relationship. }\end{array}$ & $\begin{array}{l}\text { Difference in task definition: auditors prefer a point estimate; specialists } \\
\text { prefer a range. } \\
\text { Differing views on the starting point for valuation: auditors focus on } \\
\text { materiality of the balance; specialists prefer to examine management's } \\
\text { approach to valuation and the security itself. } \\
\text { Difference in goals: auditors want an outcome that balances their } \\
\text { incentives please the client and a defensible estimate; specialists want a } \\
\text { comprehensive valuation that enhances their skills. } \\
\text { Lack of auditors' understanding of the complexity and nuance of valuation } \\
\text { contributes to tensions, which can be overcome by auditor experience and } \\
\text { FVM education. } \\
\text { Auditors take a "check-the-box" approach to valuation. } \\
\text { Auditors are overconfident in their ability to audit their client’s FVM. } \\
\text { Although specialists are aware auditors do not want caveats in reports, } \\
\text { they use them in response to last-minute requests and restricted budgets. }\end{array}$ \\
\hline
\end{tabular}


TABLE 2 (continued)

Summary of Findings

\begin{tabular}{|c|c|}
\hline Coopetition Framework Factor & Key Findings \\
\hline Project Goals (continued): & $\begin{array}{l}\text { Specialists' perceive that auditors acquiesce to client preferences over defense } \\
\text { of the specialists. } \\
\text { Risk of regulatory scrutiny prompts auditors to seek early assistance from } \\
\text { specialists. } \\
\text { Competence of the client's } 3^{\text {rd }} \text { party specialist impacts the specialist's budget. }\end{array}$ \\
\hline $\begin{array}{l}\text { Group Identity: } \\
\text { - The stronger the salience of the collective identity, the less likely } \\
\text { that tensions will dominate the coopetitive relationship. } \\
\text { - The more salient the membership to the functional unit, the less } \\
\text { likely there will be coordinated dedication and motivation to } \\
\text { achieve the coopetition project goals and the greater the } \\
\text { opportunity for tensions and conflict }\end{array}$ & $\begin{array}{l}\text { Specialists desire to be respected and treated as the experts in the alliance. } \\
\text { Specialists believe auditors inappropriately treat valuation as “outsourced” } \\
\text { testing and are insufficiently engaged in the FVM audit. } \\
\text { When specialists have a collectivist identity, they are more committed to a } \\
\text { high-quality audit and protecting the audit firm's reputation risk. }\end{array}$ \\
\hline $\begin{array}{l}\text { Knowledge Sharing } \\
\text { - Auditor reliance on the specialists' expertise gives specialists a } \\
\text { - Trronger power position (control) over knowledge sharing } \\
\text { - Trust facilitates knowledge sharing }\end{array}$ & $\begin{array}{l}\text { Specialists do not trust auditors and are unwilling to share valuation models } \\
\text { and proprietary tools with auditors due to fears that auditors: } \\
\text { - Share models with their clients. } \\
\text { - Use models on their own even though they lack the skillset to do so. } \\
\text { - Reduce their use of specialists in the future. } \\
\text { At times, when specialists do not share their models, auditors will attempt } \\
\text { valuation on their own, even resorting to a "google" model approach. } \\
\text { Specialists believe cross-training (units learning each other's craft) will } \\
\text { enhance audit quality and their ability to gain future audit support work. }\end{array}$ \\
\hline
\end{tabular}

